\title{
Tequila Sunrise and Social Action
}

\author{
Camilo Aedo, Yann Bona, Raúl García, Víctor Hernández, Marcela Olivera y \\ Héctor Robledo \\ Universitat Autónoma de Barcelona \\ camiloaedo@gmail.com; yannbona@yahoo.es; herramv@hotmail.com; \\ marcelaaom@gmail.com; raulgarciar@gmail.com; chacsol@gmail.com
}

Resumen

En este trabajo presentamos un ejercicio narrativo acerca de la acción social y las teorías hermenéuticas que han intentado definir o hablar acerca de la misma. Se recogen propuestas diversas: desde las que abogan por considerar a la acción social como un texto hasta las consideraciones más pragmatistas acerca del para is qué de la acción. En este relato se pone en juego, en el más puro sentido gadameriano, una ficción que tiene la virtud de tematizar y poner en acto, simultáneamente, elusive.

un concepto que teóricamente ha sido elusivo.

Este abordaje asume la sutil noción de narración ficticia que, de acuerdo a Paul Ricoeur, tiene la característica paradójica de que entre más irreal se sitúa una lectura, es más profunda y lejana su influencia sobre la realidad social. Por otro lado, coincidimos con Alfred Schutz en que, al abandonarnos a la risa, hay un ámbito de significado que otorga realidad al mundo ficticio y new meanings.

resignifica el mundo de la vida cotidiana.

Palabras clave: Acción social; Fiesta; Interpretación

\section{Abstract}

In this work we present/display a narrative exercise about social action and hermeneutic theories that have tried to define or to speak about it. Diverse proposals are taken: from social action considered as a text to the more pragmatic considerations of action. In this story it is put into play, in a gadamerian sense, a fiction that has the virtue of thinking and putting in act, simultaneously, a concept that theoretically has been This approach assumes the subtle notion of fictitious narration that, according to Paul Ricoeur, has the paradoxical characteristic that as the most unreal is a reading, its influence is deeper on social reality. On the other hand, we agreed with Alfred Schutz in that, when laughing, there is a scope of meaning that grants reality to the fictitious world and the world of daily life acquires

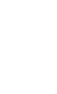

\footnotetext{
Keywords: Social action; Party; Interpretation.
} 


\section{Prefacio}

En una ardua sesión de trabajo, devanándose los sesos para descifrar la relación entre Verdad y método, I y II, con la acción social, de pronto se dieron cuenta que todo era inútil.

Yann, Raúl, Camilo, Héctor, Marcela y Víctor estaban exhaustos de tanta hermenéutica, pragmatismo, nihilismo, acción comunicativa, texto como acción, tradición, grund, verwindung... Se miraron y decidieron que era mejor echar todo a la mierda.

—Juguemos a algo —dijo Yann.

Víctor.

—Un juego que ponga en órbita a todos estos locos de la tradición posgadameriana — dijo hacer sociología.

—Sí, sí —dijeron Camilo y Marcela-. Que incluya cine y literatura, una nueva manera de

Todos se fueron entusiasmando.

Héctor se reía, como silenciosamente:

—De veras que están locos, pero me gusta.

—Estos cuates, están sueltos y sin vacunar —comentó Raúl.

Por misteriosas razones, pasaron del Santo Grial a una prima codiciable.

— Cuyo nombre no se podía decir por motivos inconfesables —añadió Raúl.

Se pusieron unas reglas ${ }^{1}$, se lanzaron a la escritura colectiva y, entre comida y bebidas, entre chistes cubanos y juegos con cubos imaginarios, fue saliendo algo que hablaba de la acción social de otra manera. Ojalá les guste; al menos nosotros nos divertimos.

\section{La invitación}

Nunca fue justo llamarla por su nombre, porque mi prima era toda acción y cualquier palabra que la nombrara no terminaba de decir lo que ella podía ser. En todo caso, también es verdad que hay motivos inconfesables para revelar su nombre, y por eso la invitación para la fiesta que a todos nos convocó rezaba:

\section{Si te gusta la acción, no importa la manera como la interpretes, estás invitada a mi fiesta. Estoy segura que te resultará inolvidable.}

Posdata: puedes traer lo que quieras para intercambiar (y aquí tampoco importa la manera como lo interpretes, sólo que será una condición de ingreso y permanencia el que lo hagas).

Lo que no puedo explicar, no por motivos inconfesables sino simplemente porque lo ignoro, es cómo pudieron llegar personajes tan peculiares y raros a la fiesta. El hecho es que acontecieron conversaciones insólitas y tales conversaciones generaron acciones del todo imprevistas y que seguramente no tuvieron intenciones previas. Como sea, lo que parece evidente es que todos los personajes se movían, en sus conversaciones y acciones, con la esperanza viva de encontrarse con mi prima y descubrir en ella el significado total de tan sugerente invitación. Claro, ella sabía suscitar suspenso e intensas emociones, lo que hacía más rica toda situación. 


\section{Más allá de la koiné}

La casa era agradable. Desprendía uno de esos aromas familiares que uno nunca acaba recordando dónde fue la primera vez que lo olió. Una invitación para aquellos a quienes les gusta la acción social. leyó la invitación.

—Vaya par de idiotas habrán montado una fiesta como ésta — pensó la primera vez que

Aún así, algo intranquilo y curioso, Mak decidió asomarse por si era cierto aquello que decían. O más bien, ver que es lo que toda esa gente reunida iba a hacer allí. Cierto es que no iban sólo a tomar tequila (desafortunadamente).

Había mucha gente y parece que algunos ya estaban más animados que otros. Tendría que ponerse a tono. La verdad es que no sabía cómo abordar a la prima. Parece que todo el mundo estaba haciendo méritos para seducirla. La última vez que la vio fue en la distinción entre movimiento y acción. Pues el movimiento como un acto reflejo no se suele considerar como acción. Así que, ¿qué es lo que la hace acción y qué es lo que la hace llamarse social?, ¿cuáles fueron sus padres y a qué se dedica ahora? Se moría de ganas por preguntárselo pero antes tenía que examinar el territorio. Ver quién estaba en la fiesta y cómo iba a presentarse. Le llevaría algún tiempo emborracharse así que pensó que mientras estaba sobrio, le daría vueltas a algo que Ricoeur le confesó a medias sobre ella y el texto:

"La historia narrada dice el quién de la acción. La identidad del quien no es, pues ella misma es más que una identidad narrativa. Sin el recurso de la narración, el problema de la identidad personal está, en efecto, condenado a una antinomia sin solución: o bien se piensa un sujeto idéntico a sí mismo en la diversidad de sus estados, o bien se sostiene que este sujeto no es sino una ilusión sustancialista.

"El mundo del texto es una trascendencia en la inmanencia del texto, un fuera intencionado por un dentro."

Los textos abren mundos posibles, nos proyectan más allá de las condiciones que pretendían describir y de las condiciones en los que surgieron.

Por cierto, Ricoeur aún no había aparecido entre las decenas de piernas y brazos que se tambaleaban agitándose al ritmo de la música.

Pasar de sobrio a ebrio era toda una transformación. Como si el gesto de alzar el vaso y llevarlo hasta la comisura de los labios fuera algo repetido una y otra vez en la historia de miles de adoradores etílicos. Uno se siente repitiendo la misma acción que en fiestas anteriores. Deleuze nos hablaría de una transformación incorporal al hablar del paso de pasajeros a rehenes en un avión dada la acción de un pirata del aire. O más que acción física, acción verbal. La declaración de alguien que proclama que esto es un secuestro. Un acto de habla, a la Austin, que transforma incorporalmente a los pasajeros en rehenes. No se sabe hasta que punto el alcohol puede considerarse un actante, algo que acciona algo para que alguien pase a ser alguien ebrio. ¿Una transformación corporal? Quizás.

Mak tenía que aclarar o aterrizar todo esto en un plano más concreto para poder hablar con la prima. Aunque quizás en la fiesta encontrara a otras personas que también la conozcan y puedan intercambiar opiniones y licores. Por lo pronto podía verse a Shütz bailoteando distendido mientras removía su trago con un mezclador con forma de paragüitas. Incluso pudo verse cómo Max Weber llegó a la fiesta. 


\section{Like a virgin}

Max Weber llegó a la fiesta con cierto escepticismo. Adusto y discreto se dirigió a la barra y pidió un Johny Walker etiqueta negra que empezó a degustar lánguidamente.

-Qué tal Max —le dijo Alfred Schütz, que ya disfrutaba de su piña colada mientras movía su cuerpecillo al ritmo del mambo number five-. Pensé que no vendrías.

-Sí, lo sé, pero ya ves - contestaba Weber acariciándose la barba blanca-. El llamado de la acción siempre me ha cautivado. La verdad es que sigo extrañándola mucho.

Schütz miró hacia la puerta de soslayo.

-Tremenda tipa la tal acción — dijo como recordando viejos agravios-. Yo también quiero ver si le puedo hacer algo, espero que aparezca pronto. Mientras tanto bailo un poco.

La música resonaba con fuerza, había globos de colores en las paredes y un cuadro de Mark Ryden $^{4}$ al pie de la escalera.

— ¿Sabes? Yo me resisto a pensarla fuera de alguna racionalidad — dijo Max Weber interrumpiendo la indolencia de Schütz-. No sé que es lo que estuvo mal, mira que lo he pensado. ¿Acaso la acción se aburrió por haberla tratado así? Primero con arreglo a fines, luego con arreglo a valores - continuaba recapitulando Weber- La acción propiamente afectiva para mí está claro. Y la acción que podríamos llamar tradicional, es decir los hábitos, las costumbres, incluso tuve el cuidado de diferenciarla de la simple conducta reactiva. ¿Te acuerdas Alfred? Aquella de tan mala reputación.

Schütz había dejado de bailar y fruncía el ceño.

- Sí; la verdad es que lo único que le admiro a Durkheim, (por cierto, ¿no sabes si vendrá a la fiesta?), es haberla tratado con aquel magistral menosprecio y con aquella simplicidad tan especial ${ }^{5}$. Claro que la acción siguió haciendo de las suyas, ya sabes cómo es.

-Pero tampoco es necesario que seas tan rudo Alfred, pareces resentido con ella —afirmó Max, mientras daba otro trago a su whisky con deliberada lentitud.

- Yo creo que lo que la acción no me perdona a mí es haberla llevado a la vida cotidiana, haberla querido involucrar en las experiencias del sentido común, y claro, haberle presentado al hombre olvidado.

\section{—Sí Alfred. Creo que exageraste.}

—Le decía: mira querida, tú estás emparentada con las pre-interpretaciones del mundo; tú eres hermana de las construcciones de sentido común. Sí, déjate llevar por la experiencia ${ }^{6}$.

Weber escuchaba con media sonrisa y miraba a Schütz por encima del hombro.

-Me lo imagino Alfred, pero fíjate -y su voz obtuvo un tono más grave- yo le llegué a conceder (porque entendí que era preciso hacerlo así) el privilegio de apoyarse en procesos reflexivos y de relacionarla con determinada significación de los resultados. Recuerdo que una vez le dije, con toda solemnidad: acción, tú serás la orientación subjetivamente comprensible de la conducta, el sentido será tu brújula. Y desde entonces no la he visto más. ${ }^{7}$

—iDesgraciada! -murmuró Schütz, y casi al instante levantó la mano sonriendo para saludar a Giddens que pasaba del otro lado del salón luciendo un gorrito de spider-man en la cabeza. Anthony Giddens también había tenido experiencias interesantes con la acción, pero tampoco la dominaba. Sus amigos lo habían rescatado de una crisis alcohólica después de fracasar con la absurda empresa de asignarle su apellido a un par de pequeñas acciones secundarias.

—Oye Max, ¡vamos a ver qué nos cuenta Anthony! —dijo Schütz mientras comenzaba a bailotear de nuevo.

Max Weber suspiró con cierto desdén. 
- ¿Con ese mentecato? — preguntó.

—Sí hombre, jvamos! —exhortó Schütz mirando con impaciencia el rostro de Weber.

-Está bien, pero no me pidas que hable mucho.

Para ese instante ya sonaba en el ambiente Like a virgin de Madonna ${ }^{8}$. El salón se llenaba de voces y exclamaciones pero no todos los presentes se conocían entre sí. Por ejemplo, alguien tenía curiosidad por un sujeto llamado Talcott Parsons y un tal voluntarismo, lo cual generaba ciertas expectativas y alguna mirada indiscreta ${ }^{9}$. Había humo de pipa y en el comedor, junto a los canapés y las croquetas, dos hombres se besaban. La gente se sentía bien, pero a la vez, muchos anticipaban inevitablemente una sensación de incompletud y de nostalgia.

— ¡Zopenco! -le gritó cariñosamente Vattimo a Jürgen Habermas.

— ¡Hola mequetrefe! —contestó el alemán con alegría.

Un desconocido comentaba de su último congreso en Londres. Al fondo del recinto se podía ver, ya muy anciano, a Wilhelm Wundt, apoyado en su bastón, con sus ojillos muy abiertos. En el techo se encendían luces verdes, rojas y amarillas. Al fin ya en el otro extremo de la sala, Weber y Schütz saludaron a Giddens.

- iHola muchacho! Veo que has mejorado bastante — dijo Schütz con cierto aire de mofa en sus palabras.

Max Weber miraba hacia otro lado. Giddens arqueó los labios en un gesto de aprobación un poco tímida. Movió la cabeza afirmativamente y balbuceó:

—Sí, ahora estoy más tranquilo.

- ¿Quieres decir que ya abandonaste tus preferencias por la estructura?

- iYo nunca he tenido preferencias por la estructura —replicó Giddens con sorprendente energía- ¡Y tú deberías saberlo!

—Vamos viejo, no te pongas así —dijo Schütz que otra vez ya no bailaba.

- Lo que yo decía era que cualquier investigación en ciencias sociales habrá de preocuparse por la relación entre acción y estructura; y que en ningún caso, óyelo bien, en ningún caso, la estructura determina la acción; claro que viceversa tampoco. Y afirmé también - continuaba Giddens que al hablar miraba hacia arriba con los ojos fijos- que todo análisis social tendría que partir de las prácticas sociales recurrentes. Ya sabes, no absolutizar ni la experiencia del actor individual ni la existencia de cualquier forma de totalidad social sino las prácticas sociales ordenadas en tiempo y espacio, ¿me explico? Se trata de atender las prácticas sociales; se trata -y su voz parecía más eufórica- de establecer una teoría de la relación entre acción y estructura, imbricadas, intrincadas en toda actividad humana.

-Me voy a mear —dijo Max Weber.

-Sí, mira Alfred, -insistía Giddens cuyo gorrito de spider-man se había inclinado y descubría su calvicie avanzada - he querido observar las prácticas humanas recurrentes, las actividades que no son creadas por los actores sociales, continuamente recreadas por ellos a través de diversos medios por los que se expresan a sí mismos como actores; entonces claro, no es la conciencia la que mediante la construcción social de la realidad produce las actividades ni tampoco es la estructura social la que las recrea; antes bien —advertía Giddens casi poseído- en su expresión como actores, las personas se implican en la práctica y mediante ella se producen la conciencia y la estructura ${ }^{10}$.

Ya en ese momento la fiesta estaba a reventar. Una animadora obesa dirigía un juego con un grupo de intelectuales a los que les gritaba con el micrófono.

- ¿¡Geisteswissenschaften!?

Y los intelectuales contestaban en coro:

— ¡Síí! —y corrían empujándose unos a otros, buscando sitio nuevo. 
-¿¡Erklären!?

- ¡Nooo! —y volvían corriendo al sitio original muertos de la risa.

—¿¡Uber-lieferung!?

— ¡Sííi! —y alguien tropezaba divertido en la trifulca.

$-¿ i G r u n d ! ?$

— ¡Nooo! —y jadeaban aparatosamente unos con otros.

—Pero entonces —cuestionó Schütz- ¿por qué la acción no está contigo Anthony?

Giddens hizo silencio y su mirada bajó hasta perderse.

-Tal vez porque ella siempre huye — contestó con un giro profundamente patético en su voz.

—Lo comprendo - dijo Schütz-. Yo por ejemplo quise ubicarla fundamentalmente en la umwelt (mi mejor terreno), en esa realidad social directamente experimentada, en esa fuente principal de los constructos de primer orden, en la implicación interpersonal cara a cara donde cada copartícipe interviene en la vida en curso del otro y puede captar vívidamente los pensamientos del otro tal como éste los construye, paso a paso. Sí, esa implicación interbiográfica, esa relación nosotros.

A pesar de su aspecto disipado y vulgar (su camisa de flores, sus sandalias viejas, su conspicua piña colada) Alfred Schütz estaba convencido realmente de que en la relación nosotros se alcanzaba el grado más alto de intimidad y que en ese vínculo cara a cara los copartícipes serían concientes de sí y de su participación solidaria en la vida del otro, al menos por determinado tiempo. Para él, eso tendría que ser suficiente e implicar a la acción y a la interacción, puestas a prueba constantemente porque las personas (según su criterio) siempre buscaban, de algún modo, la mutua aceptación. Pero a él también, la acción lo había dejado. Desde las bocinas de la fiesta, se oía Urgent de Foreigner.

-Debiste abrirle también las puertas del mitwelt, ¿por qué no? Las del folgewelt y las del vorwelt —interrumpió con sarcasmo Weber que había regresado del lavabo.

-No intentes darme lecciones ahora Max.

—Pero si todo me lo debes a mí, querido Alfred —dijo Weber mientras reía.

— ¡Bah! ¿De verdad piensas que por esa poca fama que tienes eres insustituible Max? -desafió Schütz.

Giddens los escuchaba con expresión aturdida. En el salón la gorda con el micrófono seguía animando el juego de los intelectuales

- ¿iNaturalwissenschaften!?

$-{ }_{\mathrm{i} N o o o !}-\mathrm{y}$ daban manotazos desaforadamente rompiéndose las camisas.

- ¿¡Verwindung?!

— ¡Sííi! -y alguien caía destrozando una silla.

Max Weber respondía con una risita constante y burlona. Alfred Schütz empezaba a contrariarse. Anthony Giddens intervino:

-Eh... Saben: creo que tal vez sería bueno que...

Pero en ese momento, de forma intempestiva, apareció el robusto Niklas Luhmann con un habano en la boca, una cadena de oro y muchos anillos en sus manos gigantes. 

Giddens.

— ¡Hola perros! Veo que quieren acción, ¿eh? —dijo mientras palmeaba la espalda de

Schütz sonrió con desagrado. Weber dio un trago a su whisky sin inmutarse.

-Estamos hablando de ella, Niklas.

${ }_{-}^{\mathrm{i} O h}$, muy bien! Así que se dedican a perder el tiempo. ¡Mejor coman y bailen, es obvio que ella no vendrá!

— ¿¡Y a qué vienes entonces tú Niklas!? —respondió Schütz.

— ¡Oh, jo, jo, jo! Yo vengo a divertirme viéndoles la cara —dijo Luhmann sin cortesía.

Max Weber levantó las cejas y miró hacia otra parte.

—¿Qué quieres decir Niklas? —preguntó Giddens.

— ¡Sí hombre! Que todos aquí se desviven demasiado por la tal acción. Yo creo que la acción no puede desempeñar un papel tan preponderante en las ciencias sociales, y menos en nuestras vidas, ija! Por eso propongo buscar más bien, ja la comunicación! ¡Y todos deberían seguirme!

Luhmann fumó su tabaco con orgullo. Schütz estaba perplejo.

-En efecto queridos amigos - continuaba Luhmann con vehemencia-. Si se le otorga demasiada importancia a algo o alguien eso termina por obsesionarte. ¡Que mejor que venir a la fiesta de una para salir triunfante con la otra, ja, ja, ja! Por eso digo que más bien ha de ser la comunicación el objeto de análisis elemental propio de lo social. Y además afirmo que en todo caso no se debe aceptar ya hablar de la acción como en referencia a sujetos-personas (lo cual revela el exceso de atención que se le otorga) sino que tendremos que hablar de sistemas de acción, que se dan en sociedad. Ese sistema de acción será el ámbito que genere muchas posibilidades diferentes y que cree constantemente las propias alternativas de acción, ¡siempre de acuerdo a la comunicación que se establezca! ${ }^{11}$

—Pero Luhmann, algo deberás reconocerle a la acción misma — dijo Weber con frialdad.

Luhmann levantó la cara y quedó inmóvil por un momento. Luego sentenció:

-A la acción le reconozco que sirve para mantenerse, digamos, estructuradamente en un mundo complejo.

En ese instante Giddens abrió la boca y miró con esa extraña expresión que se ve en el rostro de los que sienten que le están robando las ideas.

- Claro Weber - proseguía Luhmann con extravagancia-. Se actúa básicamente para enfrentarse a la complejidad del mundo. Para enfrentar -en ese punto sus manos dibujaban en el aire grandes círculos- el exceso de relaciones que el mundo ofrece al que actúa y para poder mantenerse a sí mismo en ese mundo. Entonces la acción, iqué cabrona!, al tiempo que se conecta con la complejidad del mundo, tiene la finalidad de enfrentar la complejidad, y así poder mantenerse ella misma como tal, ique hija de puta ja, ja, ja!. Por tanto: lo más importante de la acción no es ni la subjetividad que implica, ni los intereses que permiten estructurarla, jsino su conectividad! Su posibilidad de establecer conexiones y relaciones determinadas. Eso sí, remitiéndose siempre a las comunicaciones que constituyeron su origen ¡Ja, que cosa!

—Tu delicadeza es impresionante Luhmann. Eres una finísima persona -ironizó Weber.

Niklas Luhmann mordía su puro y sonreía. Giddens, todavía sobrecogido, quiso protestar de nuevo:

${ }_{-}$¡No Niklas, no! No es posible, ¿qué quieres decir con eso de...? 
Pero de pronto, en el salón entero hubo un silencio expectante. Desde su rincón Wilhelm Wundt profirió un reprimido insulto. Se oyó romperse una copa contra el suelo. Ante la mirada de todos, en el umbral del portón, vistiendo una elegante capa negra y gafas de gruesos cristales, aparecía, terrible, el mismísimo Hans-Georg Gadamer.

\section{Galletas de la fortuna: de críticos e interpretaciones}

Maldonado y Mondaca se habían retirado por un momento del jolgorio. De lejos escuchaban las risotadas y la música que se diluían en los grandes pasillos de la mansión. Querían conocer otras salas y otros ambientes, con la idea de encontrar en alguno de ellos un par de mujeres con las que compartir la noche o un poco de conversación. Después de recorrer unos minutos, decidieron quedarse en una sala colindante a la cocina, pues en la mesa central habían dispuestas diez o doce bandejas con canapés de diversos sabores. Era un despliegue de color y aroma que les resultó irresistible. eso son.

— ¿No habrá problema que saquemos algunos? —preguntó Maldonado—. Porque para

- Podemos sacar uno que otro de cada bandeja y el resto lo acomodamos para que no se note —respondió Mondaca, con aire de manos a la obra.

-El único problema es que no hay tragos.

—Esos deben estar en otra sala. Aunque a estas alturas de la noche yo no me complico.

No alcanzaron a comer a comer más de dos o tres canapés cada uno, cuando ingresó a la sala una chica con rasgos orientales, que vestía con un atuendo al parecer chino. Portaba una bandeja llena con unas bolitas de color caqui, un poco más grandes que una cáscara de nuez. Se les acercó y les dijo:

— ¿Desean galletas de la fortuna?

Maldonado y Mondaca se miraron y rieron. Les pareció descontextualizado el ofrecimiento. La chica también sonrió, sin mostrarse complicada por la situación.

— ¿Cuál es tu nombre? —preguntó Maldonado, con ánimo de conquista.

—Vivian —respondió la chica.

—Vivian y ¿qué más? —dijo Mondaca.

—Vivian Li.

—Ah, ¡como Vivien Leigh! —exclamó Maldonado, y le tocó el brazo a la chica en señal de cariño.

—Sí, como Vivien Leigh —dijo ella—. Pero distinto. Bueno, ¿se van a servir galletas?

Mondaca las rehusó, excusándose que eso de la fortuna le traía malos presagios generalmente. Maldonado, en cambio, más solícito con la chica, tal vez por su afán siempre dispuesto al enamoramiento, no sólo sacó una de la bandeja, sino tres.

-Como mi amigo no quiere, tomo una por cada uno. ¿Qué les parece? —Y dirigiéndose a la chica, dijo-: Si quieres te puedes quedar con nosotros y ver cuál ha sido la fortuna de los tres. suerte.

—No puedo — respondió ella-.Tengo que seguir repartiendo las galletas. Que tengan

Maldonado hizo un guiño que la chica no correspondió. Antes de cruzar la puerta, pausadamente se volvió hacia ambos y les dijo:

—No se asusten por lo que encuentren. Sólo les quiero recordar que los textos los escogió la mismísima anfitriona. Adiós. 
Maldonado y Mondaca se miraron con extrañeza después de despedirla. Eso de haber sido seleccionados por la anfitriona les resultaba extraño, más todavía considerando que no la conocían, y que su presencia en la fiesta se produjo gracias a una invitación indirecta. Maldonado tomó asiento y corrió dos bandejas para hacer espacio en la mesa. Mondaca siguió empecinado en los canapés. dijo Maldonado.

—Veamos qué nos depara el destino, o mejor aún, qué nos depara nuestra anfitriona -

-A propósito: ¿sabes su nombre?

-En realidad no lo sé. Como te dije desde un principio: a mí me invitó un amigo de un amigo. Tenía varias tarjetas y me dio dos. Una para ti y otra para mí. Ahora bien, si mal no recuerdo, se hacía llamar Acción Social. Me imagino que son esos típicos juegos de gente snob.

— ¿Y él no te dijo nada más? —insistió Mondaca.

—Sólo la contraseña para ingresar a la fiesta: HERMENEIA. Nada más.

Maldonado cogió una galleta. Eligió la más dorada de las tres. La masa era crujiente y se deshacía a la menor presión. Dentro de ella había un papelito color amarillo, que tenía impreso, en letras azules, el siguiente lema:

La importancia de Heidegger en este proceso de pensamiento no consiste sólo en haber enfatizado el nexo entre ser y lenguaje, sino sobretodo en haber pensado el ser como cuento, y no como estructura.

Gianni Vattimo.

—¿Qué fue eso? — preguntó Mondaca, acercándose—. Repítelo.

Maldonado lo repitió lentamente.

—Debe ser una broma. ¿Y sólo eso dice el papel?

—Sí; parece que está dirigida a ti.

— ¿Lo dices por mi libro?

—Sí, por eso. Ahora qué tiene que ver Heidegger con una galleta de la fortuna es un asunto que da para pensar.

-Probablemente nuestra anfitriona estaba pasando una crisis existencial y se armó todo este asunto de darle más contenido a este jueguito de las galletas.

Maldonado leyó una vez más el texto para sí, pero no halló una respuesta a sobre qué apuntaba. Trató de recordar las clases de filosofía que tuvo en el colegio y en la universidad, y a las que siempre había prestado poca atención, pero no pudo dar con un hilo conductor que le revelase algo sobre esa sentencia.

— ¿Qué dicen las otras? —preguntó impaciente, Mondaca.

— ¿Ahora empezó a gustarte el asunto? -respondió irónico su amigo, que se desconectaba de sus cavilaciones.

-Es simple curiosidad.

Maldonado abrió las dos galletas restantes al unísono. Una portaba un papel naranjo, de aspecto fluorescente, con letras verdosas. La otra tenía un recorte de diario, cortado desprolijamente. Parecía el epígrafe o el subtítulo de algún reportaje. Con calma dejó las cáscaras a un lado de la mesa, no sin antes empujar a Mondaca que trataba, infructuosamente, de quitarle 
los papeles.

- No pierdas la paciencia, hombre - le dijo- Vamos a leer primero este trocito de periódico. Y dice: "Oh, mirada resplandeciente/ ¿cómo distinguir del baile a la bailarina? W.B. Yeats" ${ }^{12}$. Yeats, me suena, pero no lo recuerdo bien.

-Es el poeta irlandés — dijo Mondaca, y repitió la última frase con lentitud, como saboreando las palabras-: ¿Cómo distinguir del baile a la bailarina? Esto parece una incógnita. Pero tiene sentido. Lo tiene.

—Probablemente se refiere a que no puedes separar la forma de la ejecución, o algo así.

-Sí, tal vez.

—Bien. Nuestra última fortuna, que parece más una señal de tránsito, dice: "Nada tiene que ver el dolor con el dolor. Enrique Lihn" ${ }^{\prime 13}$.

-Repítelo.

—-Nada tiene que ver el dolor con el dolor". Se refiere a la palabra dolor —concluyó Maldonado-. Algo así como que el dolor físico no es igual a la palabra dolor. ¿Puede ser?

-Puede ser.

Mondaca se quedó pensativo. Maldonado puso los tres papelitos sobre la mesa, uno debajo de otro. Comió un canapé y luego dijo:

-Ahora podríamos buscar relaciones. Qué nos dicen estos papelitos en conjunto. Hacer algo como un mapa astral o una lectura de Tarot.

-Eso sería una tontera. Es un asunto fortuito. No tiene nada que ver con plan o con un esquema preconcebido.

-Pero si es la fortuna, hombre. Además, ¿por qué no podemos hacer el ejercicio? Imagínate, nuestra anfitriona, que tiene el aura de destino, nos habla del ser como relato, que no lo podemos distinguir segmentándolo, y que es...

- ¿Irrepresentable?

—Sí, ¿por qué no?

—Pamplinas —replicó rápidamente Mondaca—. Mejor vamos a beber algo.

La fiesta estaba en su clímax. El salón central y la terraza estaban abarrotados de gente. Había algunos disfrazados. Había otros vestidos con tenida de gala. La mayoría bailaba o vociferaba al ritmo popero de una gorda afroaemericana, que cantaba en un alemán con acento checoslovaco.

—Esto sí que es ambiente - dijo Maldonado, mirando a su amigo que parecía cada vez más introvertido- ¿Qué pasa, hombre? ¿No te gusta la música, la gente? tonteras mías.

—No es eso — respondió Mondaca-. Estoy complicado con un asunto. Pero déjalo. Son

- Te recuerdo que vinimos a una fiesta y aunque no conozcamos al noventa y nueve por ciento de los asistentes, no significa que la vamos a pasar mal. Vamos, suéltala.

— ¡Las críticas son pura mierda! — dijo Mondaca mientras empinaba otra cerveza-. ¿Qué saben los críticos de acción o suspenso? No tienen idea.

- ¿A qué te refieres? 
—Las críticas que hicieron a mi libro. Lo basurearon sin entender nada de nada.

- A mí gustó tu libro —advirtió Maldonado—. Ahora bien, si te refieres a la crítica del "Decir es hacer". Yo creo que esa mujer rescató cuestiones buenas. Si tu libro no es pura mierda.

- Te aseguro que no dijo nada bueno — sacó una hoja de diario arrugada de su bolsillo y torpemente comenzó a leer-: "Porque Conspiración en Londres, fuera de convertirse al poco rato en un galimatías ininteligible, carece de toda orientación ética y presenta, en la pura alabanza de las balaceras, las explosiones, las muertes horribles, una chocante tendencia que, por falta de un término mejor, podríamos denominar macho-vitalista o protofascista". Te das cuenta, Maldonado, ¿qué sabe esta pendeja de acción? Mira -le mostró la hoja - se pone a alegar contra las nuevas generaciones que no leen a los grandes del suspenso. Esto es puro canon ${ }^{14}$. Ésta se cree una pontífice de lo correcto. Pero sabes qué, en cierta medida tiene razón. Ya nadie ve a los próceres, a Bruce, a Chuck, a los que fundaron las pelis de acción.

-A mí siempre me gustó Charles Bronson. Ese era un duro duro - sentenció Maldonado-. Los de ahora andan con pistolas que parecen de juguete.

-Sí, es verdad. No hay ni uno como Steve McQueen o como James Coburn. Incluso como John Wayne. Ese viejo la llevaba.

Mondaca encendió un cigarro y le regaló otro a Maldonado. En un extremo de la sala un grupo de invitados hizo alardes de jolgorio, que se confundieron con las risotadas de unos viejos empaquetados que fumaban pipas y habanos. A pesar de lo animado del entorno, Mondaca parecía no atender la situación. Estaba distraído, absorto en su problema, y mientras más pensaba, con más intensidad bebía. Maldonado, en cambio, estaba con mejor ánimo, pero preocupado por su amigo. Maldonado.

—Si te ayuda en algo, yo creo que tú tienes una desventaja con respecto a los otros — dijo

- ¿A qué te refieres?

-Es que tú no formas parte del medio. No tienes parentescos ni apadrinamientos importantes. Tú eres kinesiólogo y karateca, Mondaca. Claro, además de escritor. A mí me parece fantástico, pero eso no vende. Lo que vende son las biografías portentosas.

—Puede ser —replicó Mondaca. - Te lo agradezco, de verdad. ¿Quizás sólo sea un problema de posicionamiento, de crear imagen?

fiesta?

-Viste, es cosa que lo tomes de otra forma. Pasando a otro tema: ¿qué te parece la

-Está bien diseñada, habla por sí sola. No sé si me entiendes. Hasta los invitados parece que encajan. Aunque para ser francos, cualquier personaje encajaría aquí.

- ¿Te refieres a lo disparatado?

—Disparatado no es la palabra. Delirante sería mejor.

—Delirante sería no ligar con alguien. Basta de tragos y a la acción, Mondaca.

-Te parecerá extraño, pero yo creo que es tiempo de irme.

- Hey, hombre, ¿cómo te vas a ir tan pronto? Por último quédate por los tragos o por el baile. Además, ¿no te da cominillo saber quién está detrás de esta fiesta? Quédate al menos para conocer a la anfitriona. de ella.

-Ya te comenté que no tengo ningún interés en verla. Prefiero conocerla por lo que dicen

- ¿Cómo así? 
- Me quedaron dando vueltas las frases de las galletas. Tal vez todo sea inaprensible y lo único que hacemos es jugar con las versiones que tenemos de las cosas.

-Pero si te quedas, al menos puedes conocerla conversando con ella.

- ¿Y quién me asegura que sea con ella con quien estoy hablando ${ }^{15}$ ?

\section{Introversiones etílicas, extroversiones pirómanas}

Mak seguía con atención lo que allí ocurría. Había examinado el territorio y encontró unos tipos que habían entrado en el club de amigos de los grandes clásicos "Weber \& Co.", un par de chicos animados con los canapés, algunos acróbatas y malabaristas y más gente que no conocía. También saludó de reojo a Shotter y Austin.

Mak había dormido a duras penas la noche anterior y pronto volvió a caer en la hipnotizante copa de vino que tenia entre las manos. Aquellas frases de Ricoeur le quedaron largo tiempo marcadas. Como uno de esos giros en la conversación en el que uno se queda fijado en una sola frase o palabra mientras los demás siguen hablando.

Y allí estaba Mak. La mirada distante y desenfocada.

De hecho, ¿quién era Mak? Él quizá nunca se había preguntado acerca de su condición de existencia ¿Y qué más le daba? Él era quien narraba su historia. Mak "era" cuando daba cuenta de sus actos. A veces con más gracias y otras ebrio perdido. Pero podía reconocerse en un hilo narrativo que recorría sus recuerdos y deseos más sentidos.

La identidad de Mak se resumía en un par de líneas cada vez que se proponía pensar sobre ella. Y esas líneas y no Mak constituían su persona. Decididamente no soportaba la idea de que su vida se reconfigurara a la par que se reconfiguraba la trama narrativa de su historia. Pues todas sus acciones quedaban de algún modo registradas, figuraban en un registro histórico. Alguien podía llegar, abrir, leer su vida. Y él mismo pudo releer la suya. Así, todo lo que podía hacer era preocuparse por la interpretación de sus actos, de su vida. Y esperar que no sean otros los que se encarguen de interpretarla. Sobretodo, que no sea Heidegger, por ejemplo.

-Qué ingenuo eres Mak. hablar.

— ¡Hombre amigo! ¡No te había reconocido! ¿Cuándo llegaste? Al fin alguien con quien

Ricoeur estrechó la mano un tanto pegajosa de Mak.

-Bien. Llegué algo tarde, ¿no? Pero veo que las demás hormiguitas ya están cotejando a la reina.

—Sí, sí. Pero no te quedes allí, pasa y pídete un trago ¡Invita la prima!

Ricoeur rehusó amablemente y acto seguido retomó el hilo de lo que le había dejado inquieto en los pensamientos de Mak:

-Oye Mak, nunca vas a poder evitar que los demás te vean como lo que no eres. O más bien, que los demás se hagan de ti una lectura distinta a la tuya. Pues del mismo modo que un texto se aleja de la intención mental de su autor, y a la larga ya nada o poco tiene que ver lo que quería decir con lo que se dice de él, tus actos también son leídos. Creo que a veces Habermas interpreta tu sonrisa amable con una baba-de-borracho, por ejemplo. Y por mucho que te esfuerces esa interpretación prevalece por encima de la tuya.

- Vaya, precisamente veo que sigues siendo el de siempre. Bien, bien.

Acto seguido Mak reaccionó:

—Bueno sí, pero Habermas tiene más prestigio que yo. $Y$ además aglutina a más jóvenes padawans ${ }^{16}$ a su alrededor. Digamos que como pastor no tiene freno.

-Quizás si, pero en cualquier caso tu puedes enunciar que esa baba de borracho en realidad es una sonrisa amable. Lo que cuenta es que la interpretación no se dirime en términos de 
un ajuste a la verdad -aquí Ricoeur hizo una larga pausa para retomar aliento- ¿Te acuerdas cuando fuimos a Estados Unidos? ¿Cuando nos invitaron a dar una charla en el portaviones de la marina de los Estados Unidos? Allí estaba Rorty ${ }^{17}$, ¿no? ¿Te acuerdas de lo que dijo?

Ricoeur sonrió amablemente (sin baba) y tras una pausa incómoda prosiguió:

- La interpretación no se rige en base a una verdad por correspondencia. Es decir, no busca explicarse tal y como se explicarían las cosas que existen en este mundo de poder hablar ellas por sí mismas. Bueno, en cualquier caso, lo importante es que la interpretación no es un resultado. No es algo estático sino dinámico. La interpretación se da en la acción y es ésta quien abre las posibilidades de su realización. Como diría Gadamer: uno entra en una conversación pero no sabe cómo va a salir.

- ¡Y que lo digas!

Mak pensó en cómo Ricoeur nunca perdía la compostura y si existirían escuelas donde enseñaran a comportarse así. Pero no pensó mucho más. Mak y Ricoeur se vieron interrumpidos por un chico con traje chino que ofrecía galletas de la fortuna.

$-¿$ Galletas o chivito chino ${ }^{18}$ ?

-Vaya tela la prima esta - se dijo Mak-. Poco trabajo tiene que encima subcontrata a gente para que haga de repartidor de galletas en traje ridículo.

Ricoeur le dió un trago al licor sin perder la compostura. Mak prefirió coger una galleta y guardarla en su bolsillo para luego, examinando de nuevo el vestido encorsetado del chico.

Mak se sentía lleno de energía. Volver a encontrarse con Ricoeur le había iluminado la mirada (el vino ya había iluminado otras zonas). Y estaba disfrutando de ese instante, se sentía a gusto y contento de haber venido a la fiesta.

En ese instante alguien se cruzó con ellos. Se trataba de Gadamer que acababa de entrar a la fiesta. Y, jhorror!, con "Verdad y Método III" bajo el brazo ${ }^{19}$.

Él no lo conocía personalmente. Pero Ricoeur sí, y seguro que lo abandonaba y se iba directo a charlar con Gadamer. Tenía que hacer algo. No quería que la fiesta terminara en una discusión a tres bandas.

Por fortuna, algo pareció distraer la atención de los invitados. Ese algo era alguien. Alguien que se subió encima de una mesa y empezó a cantar una canción petarda: "Boys, boys, boys..." de la mítica Sabrina.

Esto prometía. Gadamer se asustó y agarró "Verdad y Método III" fuertemente entre sus brazos. De hecho, lo agarró aún más fuerte cuando vio que el que cantaba era nada menos que, ¡el mismísimo Umberto Eco!

La gente estaba loca. Todos vitoreando "Boys, boys, boys...". Parece que habían abandonado los "Verwindung, ¡síiiii! de hacía un rato. ¡Buf! Menudo subidón. Pero eso sólo era la antesala de lo que estaba por llegar. prima $)^{20}$ :

Tras los aplausos, Umberto se dirigió a los asistentes (quizás buscaba impresionar a la

— Hermanos, hermanas —efusivamente y casi teatralizando-. ¿Cuáles son vuestros verdaderos deseos?

Un murmullo incesante se disparó ante la escandalosa herejía "verdaderos deseos". Tras lo cual Umberto prosiguió, habiendo captado hasta la atención del chico reparte galletas.

- ¿Cuáles son vuestros verdaderos deseos? Estar aquí en esta fiesta, con la mirada distante, consumiendo galletas rancias de la fortuna y esperando gastar nuestro sueldo en el último libro que este de moda o...

Después de los últimos ruidos de vasos, copas y hielos, silencio absoluto. 
-O... ¡quemar esta fiesta de mierda! ¡Reventarla! ¡Ueee!

Dios mío, Umberto se había vuelto loco. ¿Qué nuevo mundo podía proyectar semejante derroche de energía etílica?

\section{Decir es hacer}

Escondida entre la sequedad de los arbustos afincados a orillas del río, Concepción llevó a sus ojos los binoculares con visión infrarroja para dar cuenta del lugar al que se dirigía Mondaca. Lo que vio fue lo siguiente:

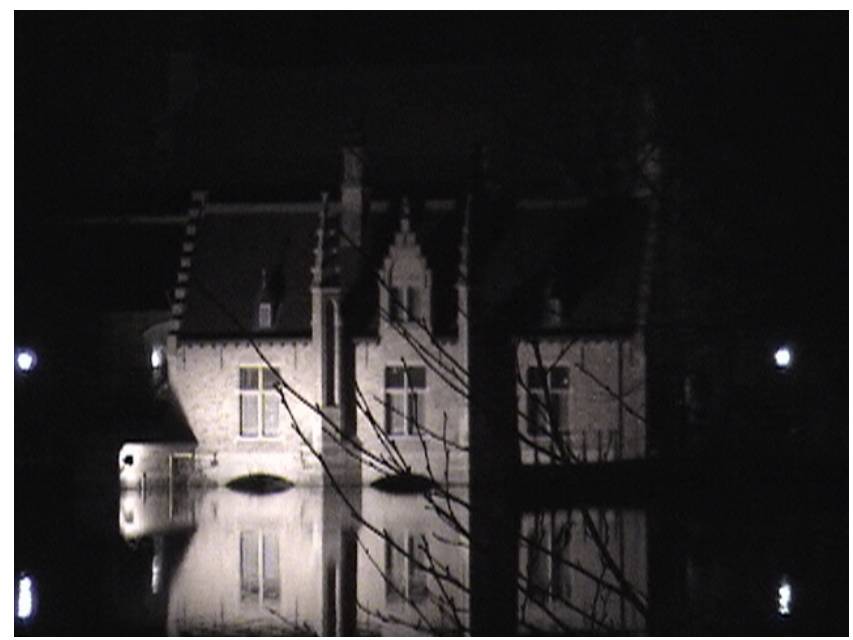

Solía decir que una buena periodista se distingue por ser conciente de que acontecimiento y ojo son una misma cosa, por lo que ponía mucho cuidado en la forma en que redactaba sus notas, pues de esta interpretación dependería en gran medida la interpretación que tuvieran los lectores de los acontecimientos relatado ${ }^{21}$. Algo con lo que su jefe no estaba muy de acuerdo. $Y$ ella se preciaba de ser una buena periodista.

Concepción justificaba su acción de acechar a Mondaca alegando estar haciendo labor periodística. Lo curioso, dicen sus colegas del gremio, es que el trabajo de Concepción consiste en reseñar eventos artísticos y culturales y de vez en cuando escribir comentarios críticos sobre novedades literarias, y el seguimiento que da a Mondaca se asemeja más al periodismo de espectáculos, al paparazzi, rayando en espionaje digno de la telebasura ${ }^{22}$.

- ¡Es que Mondaca no es cualquier escritor! —argumentaba a su jefe, el respetado profesor Ludwig, director del periódico "Decir es hacer"23.

-Seguro que no es cualquiera - le respondía él- ¿Cuántos escritores conoces que sean kinesiólogos y karatekas?

Pero el profesor Ludwig era paciente y tolerante, por lo que daba luz verde a las locuras de Concepción. Tomás, joven fotógrafo del periódico admiraba enormemente al profesor Ludwig. Le tenía por un hombre que estaba más allá del bien y del mal, un místico que podía asumir la responsabilidad de sus labores cotidianas como director de un periódico, sin la presión de vender más que sus competidores ofreciendo titulares sensacionalistas. Cuando Tomás preguntó una tarde al profesor Ludwig cómo lograba tal despreocupación, que inspiraba armonía, éste le respondió que en el mundo que él alcanzaba a ver, él mismo no existía ${ }^{24}$.

-Esto lo he discutido una y mil veces los sábados en el bar con el viejo Gadamer que comienza a estar de acuerdo conmigo - dijo el sabio profesor con una sonrisa-. Pero la diferencia entre él y yo -continuó- es que él quiere seguir escribiendo libros al respecto. Yo ya me aburrí de eso.

Al tranquilo profesor Ludwig le había dado por visitar templos y entregarse ahí a sus reflexiones. El viejo Gadamer le reprochaba en broma esta afición, a lo que el profesor Ludwig le contestaba con el verso de una canción que sólo ellos conocían: "Sigo siendo como ayer, 
subversivo y corazón, una luciérnaga perdida en el amor/ una palabra en verbo azul" 25 . Y los dos echaban a reír.

En cuanto a la actitud de Concepción respecto a Mondaca, Tomás la atribuía a una especie de fanatismo de matices adolescentes, lo que era de extrañar pues Concepción se había caracterizado hasta entonces por ser lectora y crítica de literatura muy refinada. Ni siquiera leía novelas de acción. Es más, fue ella quien publicó el comentario más duro a la última novela de Mondaca en el diario. ¿Cómo interpretar entonces este seguimiento obsesivo de Concepción hacia el singular escritor?

Lo que sorprendió a Concepción al mirar por los binoculares fue descubrir que aquella misteriosa casa medieval que asomaba entre las sombras a la que acababa de entrar Mondaca acompañado de otro individuo malvestido, y en la que a juzgar por la música a muy alto volumen y la cantidad de gente que llegaba se estaba llevando a cabo una fiesta, era la casa de su amiga más querida.

- ¿Pero qué hacen en casa de mi amiga tan distinguidas personalidades como Alfred Schütz, Weber, Giddens, y el mismo Mondaca? —-pensó en voz alta (sólo ella pensaba que Mondaca era una personalidad distinguida).

Metió los binoculares a la bolsa y caminó sigilosamente hacia el puente que llevaba al otro lado del río, cerca de la entrada de la casa.

— ¿Cómo es que mi amiga no me invitó? —seguía cavilando-. ¿Es que seguirá molesta por aquella vez que Hans, aquel hombre maduro con el que ella estaba saliendo hacía tiempo me invitó una copa? Pero no invitarme a esta fiesta es demasiado - Ya desde el puente, le sorprendió aun más ver entrar a Tomás el fotógrafo.

— ¿Y éste qué hace aquí? —espetó con cierta molestia.

—Señor Mondaca, mucho gusto. Tomás del periódico "Decir es hacer". ¿Me permite hacerle unas fotografías?

-"Decir es hacer", ¿eh? ¿Para qué quiere hacerme unas fotos el diario que destrozó mi novela? ¿Hasta dónde quieren llegar?

"Y eso que todavía no sabe lo que viene en el próximo número", seguramente pensaba Tomás, recordando lo último que escribió Concepción.

-Lo siento señor. Las opiniones vertidas por los columnistas son responsabilidad exclusivamente de ellos y no del periódico. Es más, voy a decirle algo: conozco a Concepción, la periodista que ha escrito las notas agresivas acerca de su libro y estoy casi seguro que lo hizo solamente por llamar su atención. Ella es su más ferviente admiradora.

- ¿Por qué dices eso?

- ¿No se ha dado cuenta? Lo sigue a todas partes. Bueno, la verdad es que ella no me ha dicho que lo admire, y de hecho no es muy dada a las novelas policíacas, pero a juzgar por su actitud...

- ¿Y qué tal que es una loca maniática que sólo quiere terminar de destruirme? -interrumpió Mondaca asustado. bajo el brazo.

En eso estaban cuando el temible Hans-Georg Gadamer llegaba a la fiesta con su libro 
-Concepción -le dijo aquella vez el profesor Ludwig-. Nunca te he pedido la insidiosa objetividad al escribir tus notas, pero esta vez te has pasado. Has actuado con mucha saña hacia ese pobre aprendiz de escritor. Mejor que hubieras hablado de otro libro que te mereciera mejores comentarios. Y para ser sincero, leí el libro y me gustó.

- ¿Lo ve? Usted no deja de entrometer sus prejuicios al momento de evaluar mi trabajo.

— ¿Podría ser de otro modo? — sentenció el viejo.

Unos días después Concepción pedía autorización para hacer un reportaje completo sobre Mondaca, el escritor karateka y kinesiólogo, dejando a todos extrañados.

Concepción se coló a la fiesta justo después de que entrara Gadamer, pasando desapercibida mientras todos prestaban atención al imponente hombre de capa negra. Tomás la reconoció y sintió el impulso de fotografiarla cerca del gran maestro. Pero lo que sus ojos en realidad no podían creer era que Gadamer era el mismo Hans ("¡claro! ¡Hans-Georg Gadamer!") con el que Concepción había estado saliendo, que era también el amigo de su jefe el profesor Ludwig. La mente del azorado fotógrafo empezó a trabajar muy rápido: ¿y si la amiga de Concepción había hecho esta fiesta para llamar su atención y en medio de la confusión originada por el tumulto eliminarla y así vengarse por su desliz con Hans? Tomás estaba al día de la vida de Concepción pues ella le contaba todas sus aventuras. Pero desde que apareció la mentada novela de Mondaca había estado muy misteriosa, reservada. Todos en la redacción de la revista pensaban que el joven Tomás estaba enamorado de Concepción, pero él afirmaba que sólo eran buenos amigos.

Mondaca ya hasta estaba ensayando la pose para la fotografía cuando los nervios hicieron mella en Tomás, que no dejaba de pensar en el riesgo que estaría corriendo Concepción. Definitivamente se olvidó del escritor que ya había logrado su mejor sonrisa emulando a los divos que se encontraban en la fiesta, y comenzó a disparar con la cámara fotográfica a diestra y siniestra, como si la lente fueran sus ojos que buscaban a Concepción en medio de la multitud, mientras los intelectuales allí congregados realizaban acciones que no alcanzaba a comprender. Coreaban frases absurdas, bailaban desaforadamente.

Concepción se sentía inexplicablemente bien en ese ambiente. Pasaba entre la gente, no sabía si buscando a su amiga o queriendo acercarse a Gadamer (aquél que la había seducido un martes de carnaval), o simplemente gozando del contacto de la multitud, de los colores, de la música estridente, de las bebidas bien cargadas. Cuando inesperadamente se topó con Mak, al que ya se le había bajado la borrachera al escuchar las locuras del hombre que dirigía ahora a la multitud.

— ¡Hey! Creo que nos conocemos - le dijo mientras le apuntaba con el dedo índice.

-Claro, tú eres el amigo de Ricoeur -le contestó Concepción con tristeza, pues le recordó cuando Hans le hablaba de sus colegas.

—Sí, y tú eres amiga de Rorty ¿no es así? —-dijo Mak con seguridad.

Concepción se quedó pensativa, con la mirada perdida, como añorando, y sólo atinó a decir:

— La verdad es que ya no estoy segura de nada.

-Podría decir que te entiendo. A veces tampoco sé ni quien soy.

En eso, Mak subió la mirada al balcón de la segunda planta, donde se percató que una silueta femenina levantaba el brazo como si estuviera apuntando con una pistola a alguno de los convidados. También Tomás se percató de aquella silueta.

\section{Gadamer ataca de nuevo}

Desde que había perdido la razón, Gadamer aparecía de repente en cualquier festejo. Pronunciaba palabras enigmáticas para luego, sin remilgos, entregarse a la nocturnidad. Podía deambular entre 
la gente, conversaba con algún borracho o seducía muchachas jóvenes con el irresistible atrevimiento de pasarles la lengua por la nuca. Al escucharlo, muchos afirmaban sentir grandes alteraciones emocionales, un asombro inaudito, una extraña felicidad, como si en un instante, aquellas frases modificaran la existencia. Otros en cambio, experimentaban mucho miedo y un profundo desamparo, a veces insoportable. La locura de Gadamer era vista en cualquier caso como un giro misterioso (inacabado, imprevisible) del destino. Existía incluso la creencia de que todo aquel que no era alcanzado en su sensibilidad por las palabras del pensador, nunca lograría salir de un círculo de fracasos intelectuales y a la postre, terminaría como un desconocido amargado, vendiendo alcohol o seguros de vida en cualquier enorme ciudad latinoamericana.

Gadamer levantó su mano izquierda y de ella salían erguidos sus dedos meñique, índice y pulgar en un gesto desafiante. En su dedo meñique se podía ver perfectamente un anillo plateado con una calavera brillante en el centro. Bajo el otro brazo llevaba un libro pesado, encuadernado en piel y grabado con letras de oro. Entonces dijo con voz fría:

—Lo propio de la solemnidad de la fiesta es el silencio... y a veces, el silencio se extiende.

En ese momento, como si obedeciera una orden, la mano del operador musical desconectó el equipo de reproducción sonora.

-No obstante -amenazó Gadamer en su delirio- he de decir esto: si hay algo asociado siempre a la experiencia de la fiesta, es el rechazar cualquier aislamiento de unos hacia otros. La fiesta es comunidad, la verdadera fiesta es siempre fiesta para todos...es lo que une a todos. Porque la fiesta no es sino para el que participa en ella.

— ¡Sí maestro! —se oyó una voz emocionada desde el fondo.

Gadamer avanzó unos pasos y dijo:

-Una fiesta se celebra. $Y$ una celebración no conduce a ningún sitio, no conduce a ninguna meta como tal. Antes bien, al celebrar una fiesta, la fiesta está siempre ahí, y en eso consiste su carácter temporal.

Con la boca abierta por la sorpresa la gorda del micrófono murmuró fascinada: "claro. Él habla de la palabra begehung. $Y$ acaso del verbo begehen, que aparte de celebrar, significa también caminar sobre algo. Es genial". Pero todavía con mayor acritud, como si se tratara de algún antiguo secreto, Gadamer proseguía:

-Lo propio de la fiesta es una especie de retorno - su libro dibujó una espiral en el aire- El orden del tiempo se origina en la repetición de las fiestas. No el tiempo que mide el reloj, claro, sino el tiempo que es propio de cada cosa, y de cada quien ¡Por ejemplo tú Ricoeur! ¿Ya sabes cuál es tu tiempo? —lo señaló penetrante.

Ricoeur movía su labio inferior, tenía los ojos vidriosos y no pudo decir nada. Luego con tono pausado, casi melodioso, el hombre de la capa negra continuó:

-Sí. La casa de la acción tiene su tiempo propio ¡Y ese es el tiempo festivo! En la acción tendremos que celebrar todos el tiempo propio. La celebración detiene el tiempo, nos invita a demorarnos. Ya lo decía Kant -y su mirada reflejó de súbito una extraña angustia- se trata nada menos que de la finalidad $\sin \mathrm{fin}^{26}$.

Niklas Luhmann, con toda su corpulencia, había dejado caer el tabaco y sollozaba como un niño. Alguien se acercó a Gadamer con espontánea devoción y puso en su mano izquierda un tequila sunrise ${ }^{27}$. Gadamer lo tomó con indiferencia y bebió un trago amplio, del que pudo oírse el chasquido impúdico del paso del líquido por su garganta senil. En otro punto de la sala, con un ardiente gesto de desesperación, Jürgen Habermas trataba de tomar alguna nota. 
-Es necesario encontrar el tiempo propio de la acción —dijo Gadamer recuperando la firmeza. $Y$ casi al instante, como recordando de pronto un tema puesto entre paréntesis, movió la cabeza y frunciendo el ceño preguntó:

-A ver, ¿dónde se encuentra, por ejemplo, el ritmo? ¿Eh? ¿En las proporciones físicas objetivas del tiempo? ¿En las ondas físicas objetivas, o... en la cabeza del oyente? Pues bien, lo que ocurre es que se escucha el ritmo de fuera y se lo proyecta hacia dentro. $Y$ vivir con ritmo es análogamente, vivir en la acción.

Sin poder evitarlo, Anthony Giddens comenzó a experimentar un intenso sentimiento de piedad. Por su parte, a punto del infarto, Wilhelm Wundt, aprisionado por los brazos de dos camareros, alcanzó a gritar ya sin fuerza:

- ¡Lárgate a tu inmunda guarida Hans! -hasta que otro sirviente lo amordazó, amablemente, con una servilleta de seda.

-Y tal vez, vivir en la acción sea la única correspondencia posible entre nuestra finitud, y eso que se denomina eternidad. Sí, porque sépanlo bien: es la rutilante mirada de Mnemosine, la musa que conserva y retiene, la que nos caracteriza. En efecto, lo que intentamos en nuestra relación con el mundo y en nuestros esfuerzos creativos es retener lo fugitivos. Es, podríamos decir, accionar la permanencia que brota de la fuga.

En medio de las luces tenues del recinto, con aquellas palabras flotando en el espacio, Hans-Georg Gadamer bebió de nuevo un trago generoso de su tequila sunrise. Max Weber, con su mirada puesta en algún recuerdo, sintió repentinamente una sutil amargura. Un desconocido, con sus labios húmedos por el martini, empezó a gemir pletórico de alegría. Alguien más tuvo como nunca, una sensación de deliciosa libertad.

- He de irme a bailar ya, porque si no lo hago, mi presencia aquí perderá su simbolismo, y un símbolo, ya lo saben todos, es aquello en lo que se reconoce algo (de igual modo que algún apunte en alguna conferencia, en la antigüedad, el anfitrión reconocía al huésped en la tessera hospitalis), y reconocer algo no significa propiamente sino el proceso mismo del "ir-humano-acasa", einhausung, como diría Hegel. De modo que he de entrar en esta casa, en esta fiesta, en este tiempo, pero antes, a todos los que aquí participan en la búsqueda ferviente que se intuye, quiero obsequiar, como una ruta de comprensión y solidaridad, las siguientes palabras (su mano levantó el vaso como quien hace un respetuoso brindis y luego, con voz metálica declamó):

-Phronesis... ethos... praxis...logos...

La mujer obesa del micrófono dejó sentir su risa-llanto estremecida. En ese momento con una gran exclamación que atravesó el ambiente, irrumpió, definitiva, la ovación de todos. Gadamer hizo una reverencia llena de misticismo.

- ¡Lo queremos mucho maestro!

En medio de los aplausos, Gadamer, tocó su pecho con el vaso casi vacío. En ese instante, el operador de sonido reinstaló la música con aquella canción de llya Kuryaki and the Valderramas conocida popularmente como "A mover el culo". Gadamer avanzó hacia la barra de bebidas cuando de pronto, volvió su rostro y sentenció en voz alta:

-Recuérdese esto: el pesimismo es siempre una falta de sinceridad.

—¿Por qué maestro? —gritó una voz del fondo.

-Porque nadie puede vivir sin esperanza.

$\mathrm{Y}$ desapareció ${ }^{28}$. 


\section{Viva mi desgracia}

Cualquier persona ajena a la atmósfera de delirante erudición que se estaba gestando en la fiesta hubiera pensado que aquellos locos intelectuales terminarían por llevar el mundo al caos si sus declaraciones eran escuchadas y asumidas por la gente común y corriente. Era el caso de Tomás, que si bien comprendía el lenguaje de aquellos hombres gracias a las involuntarias lecciones de su querido profesor Ludwig, era enemigo de complicarse la vida. Claro que eso hubiera podido pensarlo si no hubiera estado tan atento a la sospechosa silueta que podría representar una amenaza para los congregados. Lo primero que pensó Mak, el otro que pudo percatarse de la silueta amenazante, fue "ahí está la prima". Pero la silueta desapareció en tanto se prolongaba el seductor discurso de Gadamer. Si algo tenían en común Mak y Tomás, era justamente que no se sentían del todo parte de la fiesta. Tomás se preguntaba si Concepción, que había desaparecido entre la masa festiva, podía experimentar el sentido de pertenencia a este ambiente. Habermas, Ricoeur, Weber, Wundt... de todos ellos le había hablado el profesor Ludwig, de cómo llegaban a perderse en su elocuencia, en la inexactitud de sus palabras, en su moral autoritaria. Tomás no podía sentir más admiración que la que se profesa a aquellos que se atreven a pensar, pero no muy lejos.

"Al parecer Gadamer es el único que sigue teniendo en cuenta a la prima", estaría pensando Mak, cuya mirada desorbitada sería difícil saber si atribuirla al alcohol o a la emoción que le produjeron las palabras de Gadamer, o las lágrimas que se vislumbraban en los ojos de Ricoeur. Con esa misma mirada siguió al maestro de capa negra hasta el ocaso de su presencia en la fiesta. De pronto Mak estalló en un llanto furioso y comenzó a gritar:

- ¡¿Y para qué malgastar tanta palabrería, fanáticos de mierda? !Hagamos caso a Umberto Eco ¡ ¡ Desmantelemos este antro malhabido!

Eco, que se había retirado a la penumbra de un rincón del improvisado garito, sintió que recobraba fuerzas. Dio un trago de tequila directamente de la botella que tenía en la mesa e hizo una señal a la mujer obesa para que se pusiera a cantar. Ella comenzó a interpretar "Viva mi desgracia" ${ }^{29}$.

\section{Psicoanálisis a mano armada}

Eric miraba de soslayo aquel tumulto de gente y sus rarezas. Eran las preguntas inquisitivas de la Roudinesco ${ }^{30}$ lo que impedía que saliera huyendo de aquel lugar.

—Esta mujer está loca — pensó mientras daba un apurado trago al escocés solo que había pedido.

-Decía usted que no había leído a Gadamer -le interrumpió ella, con ese tono entre ansioso y cómplice que tenía para entrevistar a quienes habían conocido a Lacan.

Preparaba una segunda edición de su biografía sobre Lacan y había hallado ocasión para enmendar varios puntos que no le satisfacían de su trabajo anterior ${ }^{31}$. Algo que le intrigaba era que Lacan ignorara la tradición hermenéutica alemana, siendo que leía bien el alemán y había puesto mucho empeño para seducir intelectualmente a Heidegger. En realidad ese punto era parte de la suposición que tenía de que Lacan básicamente no entendía nada de su propia enseñanza y por eso no solía reconocer sus deudas intelectuales. No era que su vanidad, que no era poca, le cegara para reconocer cómo su pensamiento se coordinaba con otros sistemas de pensamiento. Era que Lacan no seguía pensamiento alguno, sino que articulaba sus discursos sólo cuando sentía que tenía un público a su alrededor. Deliraba, pero con estilo.

-No dije que Lacan no hubiera leído a Gadamer - respondió Eric- sino que esa tarde que caminaba con Heidegger, cuando ya no tenían nada que decirse, el viejo vio Verdad y Método en el escaparate de una librería y le preguntó a Lacan si lo había leído. Como Lacan le dijo que no, el viejo Heidegger lo compró y se lo regaló, diciendo que era un libro muy importante. Lacan nunca se dio cuenta que era un acto despectivo del viejo maestro, a quien ya no le importaban muchas cosas; no advirtió que era una manera de ponerlo a leer "el libro de su alumno" porque le pareció que aquel psiquiatra francés estaba medio chalado. 
- ¿En verdad Heidegger dijo "el psiquiatra necesita un psiquiatra", refiriéndose a ese encuentro con Lacan? -interrogó otra vez ella.

- Mire señora $-\mathrm{y}$ por primera vez Eric la miro directo a los ojos-. Yo no sé a dónde quiere usted llegar ni por qué me citó en este sitio de mierda. Para escribir que Lacan fue Lacan debido a sus desvaríos no tiene que tomarse tan en serio su trabajo policiaco. Le voy a decir algo que le reconozco a Lacan y que hace que me importe un bledo todas las opiniones sobre el psicoanálisis lacaniano. Yo estaba en análisis con Lacan cuando Pierre se había marchado. En esa época los psicoanalistas no dejaban de mirarlo a uno como si el análisis fuera un acto de caridad, una terapia para "cambiar". Lacan no sólo te aceptaba tal cual, sino que además tenía una curiosidad insaciable para examinar el material que uno traía. Es decir, sentías que tu jodida vida era algo. Aquel tipo no lo hacía para ayudarte, sino porque era un fisgón por naturaleza. Por eso, cuando le conté sobre el día que Pierre y yo tuvimos el accidente automovilístico, cuando le hablé de cómo apretó mi mano, de cómo ese día comprendí que todas las acciones de tu vida no son más que acercamientos a un momento como aquel, ese día Lacan rompió a llorar. No dijo nada, se levantó y se fue del consultorio. Yo hice otro tanto y jamás volví. Créame que desde entonces perdí todo respeto al análisis lacaniano y sólo me quedó la sensación de que nunca podré agradecerle lo suficiente a Lacan esa escisión, ese corte de sentido. Desde ese día el suicido de Pierre fue ya sólo su muerte y mi memoria.

Se puso de pie y se fue. Ella lo miró marcharse. En ese momento decidió que omitiría todo lo que Eric había dicho porque algo tenía de intolerable. Miró a su alrededor y pensó que no estaba mal estar en medio de una fiesta tan movida. Después de todo, era cierto que ella no había visto acción en mucho tiempo: su trabajo de historiadora siempre la segregaba del centro de la acción. Su carne no era ya trémula, pero seguía siendo carne, carne viva.

Al otro extremo de la sala, dos colombianos, inculturados desde hacía treinta años en México, con grandes aspavientos discutían:

-No sea pendejo, maestro - le dijo Alfonso a Ramiro-. Estos pinches intelectuales no conocen la esencia de la acción verdadera. Hasta tienen miedo de usar las palabras malditas de "verdad", "esencia". Lo que pasa es que siempre andan mareados con la retórica de la ciencia y la filosofía, con sus ansias de cogerse la acción como si fuera de su propiedad. Es su historia de colonizadores $^{32}$, no toleran sentirse apocados y si todo se vuelve relativo y débil, entonces hacen de su inseguridad un método y un mérito. Nosotros somos caribes, maestro. Inteligencia salvaje, intuitiva. Nos vale madres eso de coger la acción de manera precisa, con todas las coordenadas teóricas necesarias. A mí esa prima me tiene sin cuidado. Quién sabe si me la he cogido un montón de veces cuando nos hemos ido de putas. Quién sabe si no es más que una histérica. Es decir, lo que en el pueblo llaman una vieja apretada. Quién sabe si a lo mejor es una pinche ilusión para que todos vayamos creyendo que este sueño es la vida de verdad.

-Te digo que eres bien güey, Alfonso. Empiezas bien y luego desvarías con esos rollos de la vida de verdad. Yo nada más decía que sí importa leer a estos intelectuales, a pesar que de estas escenitas que no acaban más allá de alguna tragedia individual. Importan sus textos porque son los espejos de un mundo que está muy cansado de seguir este tipo de juegos de seducción. Los viejos no miran que lo vetusto no está en la carne, sino en la insistencia de seguir corriendo atrás de quimeras como la mentada prima esa. Por eso también tu desvarías con eso del "sueño de la vida de verdad", o como sea que lo hayas dicho. La acción es lo que hay, Alfonso, lo que hay. ¿Ya me entiendes?

-Entiendo que por estar pedo piense usted como un pesimista consagrado, como esos oscuros filósofos alemanes que luego acaban proponiendo mandar todo a la mierda, pero de una manera muy ordenadita; es decir, sistemáticamente. Lo malo es que luego se los toman en serio y acaban exterminando a cuanto mestizo tienen enfrente. No, Ramiro. Sus textos importan pero no para confundirse. Yo desvarío con eso de "la vida de verdad" porque quiero que se sacuda esa languidez, porque pienso que también sufre usted por la prima esa y porque, déjeme decirle, yo la conozco y usted no se pierde de mucho.

Fue entonces cuando llegó el viejo Gadamer, con su enorme capa negra y con su insolencia de apagar la música y decir frases lapidarias. Los alemanes le seguían el juego y lo vitoreaban. Muchos se unían al coro de exclamaciones que celebraban sus palabras como si fuera la fuente de la verdad. 
-Te dije que se marean con la ilusión de que se la cogerán a perpetuidad. Ya nos aguó la fiesta, dijo lacónicamente Alfonso.

Con el rostro enrojecido, Umberto Eco hizo el llamado para quemar todo aquello.

- ¡Dios mío! - gritó Ricoeur-. No se conforma con haber quemado la biblioteca de su novela. - Lo dijo con rencor, porque Ricoeur seguía sufriendo por aquel efecto de lectura de la novela de $\mathrm{Eco}^{33}$, y porque en el fondo envidiaba la experiencia del novicio Adso de Melk.

Eco no creía en ninguna acción, por eso quemaba siempre todo en sus novelas y ahora quería hacerlo con la fiesta. En realidad, hacía mucho tiempo que vivía en otra época. Estaba convencido que la acción no es más que un efecto de la televisión, aún cuando en sus libros afirmaba que la acción está en la intertextualidad de la cultura.

Pero también se esfumó aquella convocatoria pirómana de Eco cuando, sin hacer aspavientos, ella atrajo las miradas de todos. Bajaba y parecía que su mano fulminaría a uno, sólo a uno, de aquella fiesta. Si Gadamer se había asustado con la performance de Eco, protegiendo ante todo su gran volumen de "Verdad y Método III", ahora entró en pánico y soltó inmediatamente su preciado tesoro. Se dio cuenta que ya no importaba y que ella le apuntaba precisamente a él.

Fue rápido. La gente dejó de mirarla y olvidó enseguida el sonido envolvente de la bala. En cambio, quedó grabado en la memoria de todos el extraño ruido de un cráneo al ser perforado. Todos se volvieron a mirar el cuerpo tendido del gran Gadamer.

\section{Sin ti no existo}

- ¡Hans! ¡Noooooo! —Concepción reaccionó de manera instantánea a la trepidante caída del cuerpo fulminado del filósofo, abalanzándose sobre él.

Mientras esto ocurría podía escucharse "Home" de Depeche Mode en los altavoces: “... and I thank you/ for bringing me here/ for showing me home/ for singing this tears/ finally I found that I/ belong here...". Umberto Eco y sus fanáticos, la mujer obesa, Giddens, Mak, Wundt, Ricoeur, Weber, todos callaron. Habermas no pudo evitar experimentar cierto morbo que rayaba en complacencia. Concepción llorando sobre el pecho del Gadamer caído dijo con voz distorsionada:

— ¡Sin ti no soy nada! ¡Sin ti no existo!

Entonces se dejó escuchar la voz pausada de un hombre que cubría su rostro bajo la sombra de una capucha, apenas trasluciendo un abundante bigote postizo de inspiración nietzscheana, y que hasta entonces se había mantenido apacible bebiendo una triste cerveza en el rincón. Era Vattimo, conciliador disfrazado de crítico, de nihilista, presumiendo como siempre su juvenil talante, dirigiéndose a la desconsolada chica:

-Hechos no, querida. Sólo interpretaciones. El ser no es, acaece. ${ }^{34}$

Tomás quedó eventualmente pasmado, discerniendo entre buscar a quien había cometido semejante crimen e ir a consolar a Concepción. Se preguntaba qué haría el profesor Ludwig en una situación así. "De lo que no se puede hablar hay que callar"35, le dijo el profesor en cierta ocasión.

\section{... Bueno, tal vez sí.}

- ¿Qué te parece si me acompañas y nos vamos a un lugar menos agitado? Podemos conversar de cosas que te gusten e incluso hablar de literatura - le dijo Mondaca a Conce, que comenzaba a reponerse de su estupor.

- La vida tiene que seguir ¿No es cierto? Una no puede quedarse aferrada al pasado para siempre -reflexionó Conce-. Me gusta el ambiente. Están los amigos. Pero bueno, te acompaño. -Dejó su vaso en la mesa, auscultó rápidamente su cartera y miró a Mondaca fijamente, mientras éste parecía aturdido por la determinación de la chica. Entonces dijo—: Y bien, ¿a dónde vamos? 
-A pasear. A pasear. Hay varios lugares interesantes. Me dijeron que en el segundo piso hay una muestra de arte.

— ¿Te lo dijo la anfitriona? ¿Tú también la conoces?

-No, en realidad lo leí en un volante que me dieron a la entrada. Conozco a pocas personas aquí. A Maldonado —un amigo de la infancia- y a Tomás, claro. ¿A qué viene esa pregunta?

—Lo decía por simple curiosidad.

Conce le hizo un gesto de espera a Mondaca e inmediatamente giró hacia donde estaba Tomás, con la idea de despedirse de él y de contarle que ya tenía la entrevista segura. Pero Tomás parecía tan interesado en su conversación con Mak, que no quiso molestarlo. Así que cogió del brazo a Mondaca y salieron por el pasillo que daba a la escala principal.

\section{Asuntos de urticaria}

La conversación estaba encendida. Mak no aceptaba que lo contradijeran. Era uno de sus defectos. Tomás le decía que no había por qué complicarse, que era natural que ciertos criterios o aseveraciones perdieran validez o consistencia si se asumía la inevitable condición de la verdad como consenso, o como fruto del diálogo, en contrapartida de la verdad como adecuación ${ }^{36}$. Mak lo miraba enfurecido.

— Insisto que Pelé fue mejor que Maradona — dijo Mak con un gesto determinante, como queriendo terminar la conversación.

—Bueno, qué importa eso. Después de todo fueron grandes futbolistas —aseveró Tomás.

-Es cierto, dejémonos de estos asuntos. Debo reconocer que tienes razón en lo de la verdad y sus representaciones, pero hay cosas en las que no puedo resistirme a ser el intolerante que siempre he sido.

-Yo también soy intolerante en algunos casos.

— ¿Tú? No te lo creo. ¿En qué podrías ser intolerante?

- Tal vez intolerante es muy fuerte. - Tomás quedó pensativo y luego de un momento dijo-: Hay cosas que me dan urticaria. Por ejemplo, el otro día estaba en un almuerzo con unos colegas y uno comenzó a decir que le cargaba que se hicieran estudios inútiles y que se invirtiera tanto tiempo y dinero en investigaciones que no conducían a nada provechoso para la gente. $Y$ una dentista que no conocía, creo que se llamaba Claudia, le avivó la cueca y dijo que ella también encontraba que muchos estudios eran inservibles, que era mejor trabajar en cosas que de verdad le sirvieran a la gente. Entonces yo les pregunté, así con algo de ironía, qué encontraban ellos que era inservible; y me dijeron, y esto es lo extraordinario, que eran esos estudios medievales y literarios, o esas investigaciones en música sacra y renacentista; que todas de esas cosas, entre otras, claro, tenían cero valor social. Entonces yo los miré no con rabia, pero sí con urticaria ${ }^{37}$.

- ¿Y les dijiste algo?

-Fui sutil al principio, pero como no reaccionaron les tiré la caballería encima y les dije una sola cosa: que me parecía extraña esa capacidad que tienen algunos de tener una mente 
supra-consciente capaz de determinar lo que quiere el resto. Una capacidad casi mesiánica de decidir y pensar por todos.

- ¿Y qué dijeron ellos?

-Que para eso estaba la ciencia. Que con la ciencia se podían demostrar estas necesidades. Yo les eché por tierra eso y me dijeron que era tan simple como ir a la calle y preguntar a la propia gente lo que quiere. $Y$ yo no quise seguir la discusión porque era inútil. Pero como ves, eso me da urticaria.

Mak cogió dos copas de champaña y le dio una Tomás.

—Brindemos por todos los talibanes del mundo, llámense como se llamen — dijo Mak—. ¡Salud!

$-¡$ ¡Salud!

A poca distancia de Mak y Tomás había una pareja con aspecto enigmático. Ella, a pesar del calor que había en la gran sala, llevaba un abrigo grueso que le cubría hasta las rodillas. Era una mujer de setenta o más años. Regordeta y pintarrajeada al estilo de los años cuarenta. Se había sacado las cejas y en su reemplazo puso sendas líneas delgadas de lápiz marrón oscuro. Él representaba unos noventa años. Llevaba una capa negra que daba la sensación de una fuerte presencia. Se trataban con cariño y aunque no parecían un matrimonio, daba la impresión que alguna vez fueron amantes. Él murmuró algo al oído de la mujer y ella asintió con la cabeza. Se separaron. Él se fue hacia el pasillo. Ella se dirigió donde estaban Mak y Tomás.

—Tengo una invitación para vosotros — dijo la mujer.

— ¿La conocemos? —preguntó Mak, desprevenido.

-Quien soy no tiene importancia, jovencito. Un hombre quiere conversar con vosotros en privado. Es algo importante para entender lo que nos convoca esta noche.

—Puede decirnos quién es ese hombre — dijo Tomás.

—Él mismo se los dirá.

— ¿Y dónde lo hallamos? —preguntó Mak.

-En el segundo piso encontrarán un pasillo decorado con cuadros del barroco. Al final del pasillo hay una copia del Embarque para Cytherea, de Watteau. Será vuestro punto de referencia. En la imagen, los amantes se dirigen hacia la izquierda. Ustedes tomarán ese mismo sentido. Avancen cuatro puertas. En la cuarta, toquen tres golpes de esta forma: uno y dos seguidos. Él entenderá que son ustedes.

— ¿Cómo sabemos si esto no es una broma? —preguntó Tomás.

—Es un riesgo que tendrás que tomar —contestó la mujer.

— ¿Y si no vamos? —dijo Mak.

—Un golpe y dos seguidos —replicó la mujer, y luego se alejó. 


\section{Amistades de medianoche}

— ¡Mondaca! — gritó Maldonado desde un extremo del bar.

Mondaca reconoció la voz de su amigo e invitó a Conce a conversar con él.

— ¿No lo interrumpiremos? —preguntó Conce—. Está con una mujer.

-Tienes razón. El hombrón no ha perdido el tiempo.

Acompañaba a Maldonado una chica morena, delgada y de rasgos delicados. Poseía una belleza de esas que llaman clásica, acentuada por sus ojos azul profundo. Ambos se veían a gusto, divertidos en alguna conversación liviana pero fructífera para el encantamiento.

—Lorena, éste es mi amigo Jorge Mondaca, del que te había hablado hace un rato — dijo Maldonado.

Mondaca saludó a la chica y presentó a Concepción. Les dijo que era una periodista que trabajaba en un reportaje sobre su libro.

— ¿Te gusta que te llamen Maldonado, así a secas? —preguntó Conce.

-Prefiero que me llamen Daniel —respondió-. Es un asunto muy propio de nosotros eso de llamarnos por nuestros apellidos. ¿No es cierto Jorge?

—Sí, desde chicos que tenemos esa costumbre. Y tú Lorena: ¿a qué te dedicas?

—Soy terapeuta. Hago psicología transpersonal —respondió-. También trabajo con flores de Bach.

-Qué interesante —dijo Conce-. A mí me encantan esas terapias como alternativas. Yo soy bien alternativa, saben. Yo practicaba yoga.

—Yo también —interrumpió Lorena—. ¿Qué yoga hacías?

—No me acuerdo. Pero trabajábamos mucho con el cuerpo y la respiración.

—Qué bonito — dijo Mondaca- A propósito, ustedes saben dónde está la exposición de arte. Dicen que es en el segundo piso, pero como esta mansión es inmensa, no sé exactamente dónde es.

—No lo sé —dijo Maldonado—. Preguntémosle a ese chico, el de los canapés.

Trataron en vano de llamarlo porque la música estaba tan alta que sus voces se diluían a pocos metros. Mondaca lo acercó al grupo. Todos cogieron canapés y de paso le preguntaron por la sala de arte. El chico les explicó la ruta, pero tuvieron que hacer un mapa en una servilleta para registrar su orientación.

— ¿Nos acompañan? —preguntó Mondaca.

—Nos gustaría, pero tenemos otros planes — respondió Maldonado.

La despedida fue calurosa y con aire de complicidad. Los amigos sabían que una parte de su objetivo estaba resuelta. Tal vez mejor de lo que esperaban. Lorena y Daniel permanecieron en el bar. 


\section{Maldonado.}

—Me gustaría tener quince años de nuevo, pero con todo lo que sé ahora — dijo

-Eso es algo que todos quieren —replicó Lorena, algo distraída por las risotadas que causó la caída de un señor alto y medio ebrio, que tenía un gorrito de spider-man en la cabeza. Luego se reincoroporó y dijo-: Sí, a mí me pasa también. No avanzar. Detenerse en un momento hasta sentirlo verdaderamente parte de uno. A veces pienso que todo sucede tan rápido e indiferenciado que no puedo disfrutarlo o comprenderlo.

-Yo tuve una vez un profesor de arte que nos hizo un ejercicio a propósito de eso. Nos dijo que dibujáramos el recorrido de nuestra casa al colegio, tratando de registrar aquello que nos parecía relevante o de interés. $Y$ no era fácil para aquellos que íbamos siempre en bus $o$ en automóvil. No era la misma calle para uno y para otro. El profesor nos decía que ya no nos dábamos tiempo para contemplar.

- ¿Tú qué dibujaste?

-Dibujé un mapa con indicaciones de ruta. Como un mapa del tesoro. Recuerdo que en ese tiempo estaba fascinado con un libro de Julio Verne, creo que era el Capitán de quince años, y con otro de Stevenson.

—La isla del tesoro —interrumpió Lorena.

- Sí, La isla del tesoro. Gran libro. Así que hice un mapa como si fuera una geografía. Me gustó mi dibujo, pero nunca voy olvidar el de una compañera. No había rasgos de ciudad en su dibujo. Sólo animales y personas y cosas que le interesaban. Los colocó sin orden específico y cada uno con su nombre. Su perro, del que se despedía a las siete de la mañana. También su mamá, el gato del vecino, la vecina que salía trotar como a esa hora, el guardia del colegio, y tantos más que ni me acuerdo. Yo en ese tiempo no me imaginaba representar un viaje por una ciudad sin considerar el cemento.

- Cada cual ve lo quiere o lo que puede ver. No sé cómo lo habría hecho yo. Tal vez le hubiera dado importancia a los colores.

- Imagina que les pedimos a todos los invitados que dibujen un mismo trayecto. Por ejemplo, ese señor de allí en la esquina. Estoy seguro que privilegiaría las carnicerías o las panaderías.

—No seas malo.

—O la chica de allí. Ella daría importancia a las tiendas de moda. ¿No lo crees?

-Pienso que ella no se preocuparía tanto de ese tema. La de allá, la que está bailando con el de chaqueta a cuadros. Ella sí que se tentaría por dibujar las tiendas.

-Es curioso: una misma ruta que nunca es igual ${ }^{38}$.

-Incluso para nosotros nunca es la misma.

- ¿Quieres bailar?

- ¿Por qué no? 


\section{El hombre de la máscara veneciana}

Mak no tenía intención de conversar con ese hombre. Le parecía una broma de mal gusto y no estaba dispuesto a pasar un bochorno. Tomás tuvo que prodigarse en argumentos para convencerlo. Siguieron las indicaciones de la mujer y aunque algo extraviados al principio, lograron dar con la copia del Watteau. Mak no conocía al pintor, pero le llamó la atención lo delicado de las formas y lo galante de la escena. Tomás, que había tenido un período de afición por la plástica, le contó que era un artista del Rococó. Pero no cualquier artista. Watteau le gustaba más que Chardin y que Fragonard, y que cualquier otro del barroco. Le dijo que había una tristeza peculiar en su obra que le llamaba la atención. Que en medio de escenas galantes, en medio de la fiesta, Watteau siempre dejaba ver pequeños matices de introspección y vacío. Pequeños detalles de ternura o gozo, como si los personajes supieran que aquellos fueran momentos únicos e irrepetibles, que debían aprovechar.

—Veo que te gusta mucho el pintor — dijo Mak.

-Como otros tantos —señaló Tomás-. Ésta es una copia del Embarque. Aquí los amantes se embarcan a la isla de Citerea. ¿Sabes qué es Cytherea?

-Ni idea.

-Pues la tierra de los amantes. Ellos se embarcan para realizar el viaje, que es su amor. Es un bello cuadro.

- ¿Cuál dirección teníamos que seguir?

—La misma dirección de los personajes.

- Hacia la izquierda, entonces.

—Cuatro puertas, un toque y dos seguidos.

Encontraron la puerta y tocaron como les había indicado la mujer. La puerta pareció abrirse sola. La sala era amplia y estaba temperada por el fuego de una chimenea. Junto a ella, de espaldas y sentado en un ominoso sillón de cuero, había un hombre que fumaba. Mak y Tomás permanecieron a la entrada, observando. Entonces el hombre, sin moverse, les dijo:

—Les esperaba. Adelante. Acérquense.

Le hicieron caso. Cerraron la puerta y caminaron hacia él. Cuando estuvieron cerca, vieron que llevaba una máscara veneciana y una capa negra. Era un hombre macizo y de mediana estatura que fumaba una pipa empedernidamente.

—Asiento —les dijo. No se queden ahí parados.

— ¿A qué viene vuestra invitación? —preguntó Mak.

—Quiero compartir con ustedes algunas experiencias.

— ¿Experiencias? —inquirió Tomás-. ¿Qué clase de experiencias?

—Las que le sirven a uno para comprender lo busca.

— ¿Cualquier cosa que uno busca? —dijo Tomás. 
—Sí, cualquier cosa. Incluso lo trascendental.

—Bien, si es así, adelante. Comparta sus experiencias — dijo Mak, con un tono algo irónico.

El hombre vació el interior de su pipa sobre las cenizas en un extremo de la chimenea. Luego cogió una porción de una yerba color caqui, que tenía sobre una mesita de centro. Presionó fuertemente la yerba sobre la pipa y la encendió. Un olor intenso se desprendía. Un olor a bosque que inundó rápidamente la sala. Aspiró tres o cuatro veces hasta que la yerba se asentó ${ }^{39}$.

—Prueba —le dijo, lacónicamente, a Mak.

Mak se mostró reacio pero la aceptó. La primera bocanada le irritó la garganta y tosió, involuntariamente, varias veces.

—Continúa, debes acostumbrarte —le dijo el hombre.

A la tercera bocanada ya no tuvo problemas. Luego le pasó la pipa a Tomás.

—Ahora hablaremos de sus experiencias — dijo Tomás, mientras le devolvía la pipa al hombre.

—Sí, ahora acaecerán las experiencias —respondió el anciano—. Les deseo un buen viaje.

\section{Objetos vacíos}

- Yo creo que estamos perdidos, Jorge - dijo Conce, mirando en todas direcciones y tratando de reconocer algún punto de referencia.

—Debe ser por aquí —respondió Mondaca—. Mira, allí está la mampara Art Deco. ¡Al fin dimos con la bendita muestra!

Cruzaron la mampara y una joven vestida de traje les recibió. La exposición estaba organizada en seis salas y en cada una de ellas había obras de artistas diferentes. Según la recepcionista, lo más top de Nueva York, Londres y Berlín. Les dijo los nombres de cada artista pero ni Mondaca ni Conce los conocían. Así que tomaron unos catálogos y comenzaron la visita.

La primera sala estaba entera escrita con palabras. El piso, las paredes, los cuadros, los objetos, el mobiliario. Todo estaba escrito con palabras. Distintas palabras y nombres, manuscritos o en imprenta, con letras fluorescentes, que se veían perfectamente a pesar de la semipenunbra de la sala. Conce trató de buscar un lugar que no estuviera escrito, pero no lo halló. Mondaca buscó infructuosamente su nombre en los objetos. La obra había sido hecha por un tal Anthony Gormley y se titulaba "Objetos Vacíos". El catálogo daba unas pequeñas indicaciones de la biografía del artista y un escueto comentario crítico. A Conce lo que más le llamó la atención fue el epígrafe de la obra. Debajo del título, Gormley puso un par de versos de Octavio Paz que decían: "Reposan a la sombra de sus nombres/ las cosas..." ${ }^{40}$.

— ¿Qué te parece? —preguntó Mondaca.

—Arte contemporáneo — dijo Conce-. Habría que ver la crítica y los comentarios como para entender algo. 
—A mí me parece obsesivo y esquizoide.

Una mujer de unos cuarenta años entró a la sala. Saludó a ambos y como si conociera del tema, recorrió con soltura la obra. Mondaca le preguntó qué le parecía. Conce le dio un pequeño tirón de brazo a Jorge porque le parecía una desubicación la de dirigirse a la desconocida. La mujer notó el gesto de Conce.

- Me parere una brutal muestra de nuestra condición de seres comunicantes — dijo la mujer- Como si hasta el más mínimo gesto tuviera un significado social. Según como lo mires, puede ser deprimente o maravilloso.

— ¿A qué se refiere? —inquirió Mondaca.

—A que estás condenado a ello. No puedes escapar.

- ¿Aunque vaya a otras salas?

—Aunque vayas a la mismísima sala principal y te entrevistes con el famoso arquitecto.

\section{"El Gabinete del Doctor Gadamer"}

Después de seis o siete bailes, Daniel y Lorena se sentaron para descansar. Estaban exhaustos con la variedad de ritmos. Reggae, Pop, Tecno. El DJ era un ecléctico obsesivo, decía Lorena.

Más invitados llegaban a la fiesta. Algunos se integraban al jolgorio, dejándose llevar. Otros provocaban desmanes. Uno bien gordo dijo algo de incendiar la mansión. Qué era eso, se preguntaba Daniel. Debía estar loco. Pronto lo calmaron y siguió la música.

— ¿Qué tienes pensado hacer más tarde? —preguntó Maldonado.

—Sé a lo que quieres llegar. Pero no estoy apurada — contestó ella sonriendo—. Quiero ver más del ambiente. Ver qué más pasa en otras salas.

-Si quieres recorremos un poco.

-Vale.

La fiesta no sólo era una expresión de risa y desenfreno. También, extrañamente y sin que alguien lo hubiera previsto, había gente llorando y algunos tristes, encerrados en sí mismos, al extremo de alguna sala, o a la sombra de un balcón. Lorena buscaba un lugar más privado, más íntimo. Dieron con una sala que parecía apropiada, pero apenas encendieron las luces, una pareja trató nerviosamente de taparse los cueros. Los cuatro se quedaron perplejos. Lorena buscó el interruptor para apagar las luces. En ese momento la chica, que no tenía más veinte o veinticinco años, dijo: "Max, hazme el favor de decirle a estas personas que se retiren, por favor". El hombre, bien entrado en años, se levantó con ánimo desafiante. Daniel pidió calma. En eso Lorena apagó las luces y se retiraron corriendo entre risas.

Corrieron por entre los pasillos, sin una dirección preconcebida. Esquivaban a los invitados, a los mozos, y a más de alguna pareja mareada por la bebida. Se detuvieron a la entrada de un pasillo ancho. Al fondo, un hombre menudo pedía boletos a una pareja. Intrigados, 
Lorena y Daniel se acercaron.

— ¿De qué se trata esto? —preguntó Lorena al hombre.

—Es una función teatral, señorita —respondió en tono elocuente.

— ¿Cuál es la obra? —inquirió Maldonado.

—Es "El Gabinete del Doctor Gadamer"41 —respondió solícitamente-. Es una obra muy moderna

— ¿Hay que pagar? — dijo Lorena.

—No, no es necesario. Pueden entrar si gustan —indicó el hombre.

—Bien, pero sáqueme de una duda — dijo Maldonado—. Hace unos momentos usted les pedía boletos a una pareja. ¿Por qué nosotros podemos entrar sin ellos?

—Eso depende del contexto, señor. Depende del contexto.

El salón era amplio y alto. Al centro había dispuestas veinte o veinticinco sillas estilo Luis $X V$. Delante de ellas, se extendía un telón de dos piezas. Al extremo derecho de la sala había una mujer sentada en una silla. Llevaba el pelo azul tomado como un copete, y un traje de dama de los años veinte. Era enjuta y tenía el aspecto de una viuda. Como espectadores había cinco personas más: la pareja que entró antes que ellos, otra pareja de ancianos y un hombre gordo medio dormido.

Lorena quiso sentarse en las sillas de más atrás, pues no deseaba interactuar con los actores, si es que éstos pedían algún voluntario para algo. Apenas tomaron asiento, el hombre de la recepción cerró la puerta con solemnidad. En seguida apagó las luces y dejó sólo una que daba al centro del telón. El gordo que estaba en primera fila reaccionó, al parecer por instinto, y se frotó los ojos para despertarse mejor.

La mujer de pelo azul pronunció unas palabras extrañas y quedó nuevamente en silencio. Un hombre salió de atrás del telón. Llevaba una máscara veneciana y una capa negra. En su mano derecha tenía un bastón como los que usan los magos. Por lo rasgado de su voz, y por su postura algo encorvada, se trataba de un anciano.

—Damas y caballeros — dijo con solemnidad el hombre-. Todo cuanto veréis es una fábula. Una fábula de la existencia. Una fábula del juego que somos. Una fábula de nuestro acaecer $^{42}$. - El hombre levantó su bastón y lo bajó rápidamente, al momento que vociferaba-: ¡Que se levante el telón!

El menudo recepcionista trató torpemente de correr las piezas del tela. Pero una quedó estancada a medio camino. El anciano le ayudó a correrla.

El escenario estaba vacío. Luego de un minuto o tal vez dos, apareció otro anciano de bigote. Hizo una venia de saludo y los de la primera fila, incluyendo el gordo somnoliento, aplaudieron. Daniel y Lorena no entendían bien de qué se trataba la presentación.

El anciano vestía de frac. Parecía un típico mago. Una voz del fondo de la sala gritó el nombre: ¡Martín, el mago! Nuevamente hubo aplausos.

Una joven, que vestía una mini y un escote voluminoso, le trajo una mesita que tenía la 
gracia de ser giratoria. El mago se dirigió al fondo de la sala y con dificultad arrimó una casa como de muñecas y la colocó encima de la mesa. Luego la joven la indicó al público con efusividad. El gordo miraba expectante. Enseguida el mago abrió la casa de par en par, y sin pronunciar palabra alguna, señaló a todos que dentro de ella no había nada. Luego la cerró. Daniel alcanzó a ver que la casita tenía una tablillita que decía: "La casa del ser". Le resultó curioso.

La joven le entregó al hombre una radio pequeña, que éste cogió con un gesto de solemnidad. Presionó el botón de play y un ladrido de perro se repitió varias veces. Abrió la puerta de la casa e insertó la radio adentro.

Lorena estaba extrañada. También Daniel.

El mago cubrió la casa con su capa. Dio varias vueltas a la mesa y tocó el promontorio con su varita. Luego sacó la capa y abrió de golpe la casa. Adentro había un perro que mordisqueaba juguetonamente la radio. El mago quedó estupefacto, como casi todos en la sala. La joven hizo las venias al público, que aplaudía con ánimo, mientras el viejo trataba de quitarle la radio al perro. El hombrecito recepcionista, con la mayor agilidad que le era posible, corrió el telón.

Nuevamente apareció el viejo con la máscara veneciana.

Lorena le dijo a Daniel que se fueran, pero éste la retuvo. Quería ver qué seguía de todo esto.

—Esta fábula es un movimiento que nos impregna — dijo el hombre-. Es imprevisible. Lo real es creado por la conciencia, como la conciencia es creada por lo real.

El anciano se retiró. El telón también. Dos actores, un hombre y una mujer quedaron en el escenario. Comenzaron un diálogo típico de los matrimonios, coloquial y despersonalizado. Todo era normal hasta que de pronto la mujer se echó a llorar, mientras una grabación continuaba el diálogo. No eran ellos quienes hablaban. Era una grabación. Pero en un momento la mujer usó su propia voz y increpó al hombre su torpeza. Le dijo que nunca era capaz sostener el guión previsto. Que siempre cometía errores. Él le reprochó lo mismo a ella. Que siempre se equivocaba y cualquier cosa la distraía ${ }^{43}$. El recepcionista corrió el telón.

Lorena le dijo a Daniel que por favor se fueran de allí. Que todo eso la tenía cansada. Más todavía el viejo sentencioso que presentaba los números. Daniel cogió de la mano a Lorena y se dirigieron a la puerta, pero antes de salir se detuvo, sin saber por qué, para escuchar las palabras del viejo: "Preguntar es siempre abrir una puerta a la realidad cuestionada".

Se fueron de allí en silencio.

\section{Lapidaciones}

El chico que servía los tragos, caminando con la mujer oriental de las galletas de la suerte:

- La acción no existe, sino el deseo, es decir el avance hacia un objeto fantásmico. Es el falo diría Lacan, pero él sólo deliraba. Mientras hablaba se iba haciendo un guión para lo que restaba del día al lado de la chica.

Giddens: 
- Ya sabía yo que esto no podía acabar bien. Malditas consecuencias no intencionadas. Y yo que esperaba que el viejo me prologara mi estudio sobre "las novísimas reglas del método sociológico".

Alfonso:

- Vamos, vamos, siempre es posible continuar la parranda en otro lugar La muerte nos anuncia que todavía estamos aquí. Esto nos sacude, pero también nos recuerda que tenemos que cargar con esos cuerpos.

-No puedo - dijo la Roudinesco, renunciando al único atrevimiento que tuvo esa noche con el pobre Ricoeur-. Se me atraviesa su recuerdo cuando te toco esa piel plegada por surcos de tantas historias de la filosofía — se vistió enseguida y regresó a su París y sus olvidos. decía:

Es raro, pero una de las esquelas de "Spiegel", sobre la horrenda muerte de Gadamer

Los acontecimientos, si acaecen, es porque son como gotas de lluvia que dejan de serlo al caer, al escurrirse como el agua de lluvia. No existen hasta que hacemos una historia, una imagen, algo que tiene una forma y que solo es ya memoria. Pero la memoria, esa duración del pasado que hace que el presente y el futuro existan, es todo lo que tenemos.

Claro, la clave está en el dispositivo de la mirada, la que se enfoca en la caída de los objetos. El reportero no era alemán, es evidente. Además, generó una demanda contra el diario "Spiegel" por parte del Consejo de honor de la Universidad de Heidelberg.

En “L'Observatore Romano" otra esquela, igual de extraña, rezaba (faltaba más, en Roma):

Pero no, las acciones no son nada de eso. Son como el tiempo y el espacio, una dimensión más de la naturaleza, una entidad física pues, que no se puede describir sin significados emocionales.

La acción social es la materia de los mitos, de la magia, de la tecnología, de los sueños. teología.

Lo firmaba un cura que era parte del comité para el diálogo entre las ciencias exactas y la

\section{... Vuelta}

—Hostias —fue lo más articulado que Mak pudo expresar cuando oyó el disparo.

Toda la sala se quedó en silencio. La verdad es que nadie tenía un hueco en su agenda para los imprevistos. Y menos para los que terminan con el devenir de Hans. Quizá ahora veamos que tan importante es el autor, como sobrevive la obra a las acciones que sobre ella el autor determinaba. Mak pensó que esos pensamientos eran algo frívolos pero lo cierto es que no podía evitar que afloraran en su conciencia. Entre tanto estupor parecía como si el tiempo se hubiera detenido. Como si la sucesión cronológica de instantes se sustituyera por una profundidad creciente en sí mismo. Y allí permaneció Mak en un instante duradero.

Mientras, cerca de la entrada, Tomás observaba atónito lo que acababa de ocurrir. Su mente fotográfica no podía evitar pensar en qué velocidad, en qué apertura de diafragma hubiera captado mejor el impacto de la bala en la cabeza de Gadamer. Pero no quiso tomar fotos de aquel trágico acontecimiento. Antes lo hubiera hecho sin ni siquiera pensarlo. Y mientras pensaba en ello, recordando su etapa de aprendiz entusiasta, la acción no se detenía. De hecho, había una multiplicidad de temporalidades que se entrecruzaban en aquello que conveníamos en llamar tiempo. Y las miradas de Concepción buscando a Tomás no coincidían con la profundidad en que Tomás había caído.

$$
\begin{aligned}
& \text { — ¡Tomás! —Concepción reposó su mano en su pálida tez para ver si reaccionaba. } \\
& \text { —Tomás, ¿estás bien? } \\
& \text { —Sí. Es sólo que... }
\end{aligned}
$$


—Vamos, aquí ya no hay nada que hacer. Cambiemos de aires.

Concepción quería salir de aquella escena, ¿negando la realidad?, ¿actuando como si nada hubiera pasado? A lo mejor estallaría en llanto, pero ahora no. Ahora no. Deseaba conocer más a fondo a Mondaca y la muerte de Hans, aunque dolorosa para todos, no dejaba de ser la muerte del padre. Así que como dicen los mexicanos: ¡La muerte del padre estuvo padre!

Habría que ver que mundo se proyectaba ${ }^{44}$ ahora que la energía etílica parecía más la antesala de la resaca que no la mecha encendida de un cargamento de explosivos. Pero Concepción acababa de llegar. Así que había que considerarla aún en la categoría de explosivos.

Mak, al contrario, seguía en su particular implosión. El pasado volvía a él en el presente. Puro chorro de energía que por instantes le hacía volver a la persona lúcida que acostumbraba ser en las primeras copas. Con un gesto autista sacó la galleta de la fortuna que guardaba en su bolsillo. No la comió. Sólo se interesó por el papelito grasiento que residía en ella:

Nacerán dudas para comprender de este modo el mecanismo de interpretación, debido a la invencible tendencia que nos lleva a pensar, en cualquier ocasión, las cosas más que los progresos.

H. Bergson.

Eso era justo lo que le pasaba a Mak. Tendía a percibir la realidad como algo ya dado. Independiente de lo que se haga en y sobre ella. La veía como algo estático. No dinámico. Ricoeur ya lo había llamado ingenuo, ahora comprendía por qué. Así, lo que hay no es lo que hay, si no lo que se ha hecho. Algo que por otra parte está permanentemente haciéndose y haciendo. Una bonita dualidad estructural ${ }^{45}$, sí. Cuando la bala salió del cañón de la pistola, se movió. Progresó hasta detenerse en Gadamer. Y no podía pensarse que la bala había estado en cada punto de la trayectoria de muerte que había unido a Gadamer y el cañón. La bala no había estado en el punto intermedio de la trayectoria. De haber estado allí hubiera hecho dos recorridos. Del cañón al punto medio y de allí a Gadamer. No. La bala simplemente pasaba. Demasiado rápido para el ojo humano, sólo veíamos el humo del disparo y la muerte de Gadamer. No veíamos el progreso de la bala. Quizás con la prima ocurría lo mismo. Todos la veían reposada en la barra tomándose su white russian ${ }^{46}$, con Ludwig en una fotografía enmarcada en la escalera, en su bailoteo particular, etc. Pero pocos se fijaban en las relaciones, en el va y ven de sus palabras. La verdad, es que la prima tanto más se escapaba cuando una intentaba esperarla en la barra o esperaba verla en la fotografía. Pues cuando ya estaban en la barra esta ya no nos decía nada de porqué había ido allí. Y cuando los ojos se fijaban en la fotografía, a uno se le escapaba porque la prima había estado allí. Era como si de una luz blanca uno sólo hallaba el rojo allí, el amarillo más allá, el azul en el piso de arriba, sin lograr adivinar que una se tenía que desplazar lo suficientemente rápido entre esos colores para componer la luz blanca de la que provienen. Mak no era tan rápido. Ni por asomo. Así que abandono su particular implosión para ver que había transcurrido ya largo rato. Tomás estaba cerca de él. Lo miró como reconociendo el estado de profundidad que antes él había alcanzado. Y lo invitó a una copa.

— ¿Hola, estás bien? Soy Tomás, fotógrafo del periódico "Decir es hacer", ¿lo conoces? -Mak no respondía, Tomás insistió:

$-¿ T e$ apetece un trago?

-No gracias. Ahora ya no. Bueno, no por lo de Hans, si no porque ahora ya no queda whisky del bueno. Je, je, je, je.

$$
\begin{aligned}
& \text { —Je,je,je,je. } \\
& \text {-Ja, ja, ja, ja. } \\
& \text {-Ji, ji, ji, ji, ji. }
\end{aligned}
$$

Ambos vislumbraron que se iban a entender perfectamente sin mediar palabra alguna. 
En el piso de arriba Mondaca seguía intentando seducir a Concepción. Pero Concepción era muy hábil. Le gustaba el juego. Ver por donde llegarían las primeras insinuaciones, las primeras caricias.

—Dicen que si un sentimiento lo escondes crece en intensidad — giró la cabeza para ver los ojos de Mondaca.

- Yo creo que es mejor expresar los sentimientos cuando surgen. A veces uno se queda con ellos demasiado tiempo.

—Sí, quizás tengas razón.

- ¿Por qué lo has dicho?

- ¿Qué?

—Lo de la intensidad, ¿hay algo que te preocupe? —Concepción se asustó, no quería ningún análisis en profundidad de sus palabras. Y más cuando sólo lo había dicho para jugar un poco.

—No, no - sonrió-. Es sólo que bueno, lo de Hans me ha afectado un poco.

Había cierta tensión entre ellos. Se podía percibir la intranquilidad de Conce. Mondaca apresurándose alzó los brazos para acogerla. Ella dudó y lo miró largo rato. Era fácil imaginar porqué Gadamer había salido con ella. Se aproximó suavemente y a ritmo lento hasta que se quedó a dos dedos de Mondaca, muy cerca, demasiado cerca. Podía oírlo respirar agitadamente. Esperó a que Mondaca cogiera la iniciativa.

—Ven aquí —Mondaca la cogió suavemente por la nuca y acercó su vibrante cuello a sus labios. La besó y le susurró al oído:

- La próxima vez que quieras rollo no hace falta que me sueltes una frase de "Tigre y dragón" sobre los sentimientos guarrona. ${ }^{47}$

A concepción se le aceleró el pulso, se sonrojó, se quedó parada pensando qué decir, qué hacer, mientras Mondaca ya había empezado a escalar la entrepierna. Finalmente le propinó un mordisco a la oreja. Mondaca se extrañó:

$$
- \text { ¡Ay! }
$$

Concepción se fue sin mediar palabra alguna. Aunque esta vez, el no mediar palabra alguna no era porque supiera que se iba a llevar bien de inmediato.

El murmullo de la fiesta volvió a los oídos de Mondaca, preocupado por hallar cuan profunda había sido la mordida, mientras Conce se alejaba ruidosamente y a paso ligero. De algún modo era tarde, y se notaba.

En la habitación del anciano el humo se hacía cada vez más denso y la garganta de Mak a duras penas resistía. Se acordó de aquella vez que sacó los ojos vomitando por la ayahuasca. No era un vómito de esos graciosos en los que uno puede coger el mondadientes y divertirse seleccionando los tropezones más ocurrentes. No. Era un vómito de muerte, pura exhalación del soplo divino, del "élan vital". Pero en aquella ocasión sobrevivió. Y esa pipa, aunque peleona, no era para tanto.

-Buen viaje, buen viaje - Tomás casi estaba en trance. Su cuerpo no estaba tan acostumbrado a los viajes como su rostro parecía sugerir.

Mak tenía ganas de conversar, el humo penetraba sin demora en sus pulmones pero aun le quedaba un rato, lo notaba. Miró al anciano y se dijo: "si el puede, ¿por qué no voy a poder yo?" 
-En una conversación —Mak tosió repetidas veces-. Perdón, en una conversación usted gana información que yo le doy, pero al dársela yo no pierdo nada. ¿O esta vez si que pierdo algo? Uh, misterio, misterio. Bueno, usted nos citó aquí de forma misteriosa, así que diga pues que es lo que quiere. Para misterios ya tenemos a la prima.

El anciano no pensó en la perseverancia de Mak, pensó que la pipa actuaría mucho más rápido. Pero daba igual, sólo tenia que entretenerlo un poco más.

-Veréis, hay cosas que no se dicen. Se experimentan. $Y$ una vez experimentadas se comprenden. $Y$ una vez comprendidas se olvidan las palabras que llevaron a esa comprensión. ${ }^{48}$ Así que cuanto antes dejéis de hablar, antes lo habréis entendido.

Tomás balbuceó:

— ¿Dónde puedo hallar al hombre que ha olvidado las palabras? Con él me gustaría hablar.

-Tomás, no le hagas caso. Déjate llevar por el humo, no sé que es pero creo que nos llevara allí donde la fusión de horizontes es más intensa. Y deja de darle coba al anciano, que está tan colocado como nosotros. llevar.

Seguramente Mak se equivocaba. Pero con una sonrisa boba Tomás le hizo caso y se dejó

\section{El delirio de Tomás}

Entonces vi que detrás de la montaña había otro horizonte, más próximo y cercano que el anterior. Me acerqué a él y cuando estuve a su lado le dije: "No huyas de mí, pues quiero alimentarme de tus aguas". Y el horizonte me contestó: "No debéis preocuparos, pues no puedo huir de tu presencia. Tú y yo somos uno ${ }^{49 "}$. Y cuando hubo dicho aquello, una luz se congregó a nuestro alrededor, y de ella aparecieron potros que galopaban en dirección de un vasto cubo.

Caminé hacia el cubo presuroso, pensando que allí encontraría a mi semejante. Varias horas caminé por entre dunas. Pequeños animales salían a mi paso: nerviosas serpientes, oscuros escorpiones y cangrejos del porte de una marmota, seguían mis pasos con los ojos de la muerte.

Y cuando llegué al cubo, vi que éste tenía cien pies de diámetro y se extendía por igual número hacia el cielo. Era todo de piedra rojiza y pulida. Rodeé el cubo mas no encontré en él puerta alguna. Desesperado, comencé a golpearlo con una vara que hallé en la tierra, hasta que de pronto, la vara se hizo fuego, y la arrojé al suelo. De allí brotó un pequeño árbol con numerosos frutos, que como signos pendían de sus ramas. Entonces cogí un fruto y pensé: "La realidad está envuelta en un mito" ${ }^{50}$.

Y cuando hube terminado de comer el fruto, de la piedra se abrieron grietas, y las grietas formaron un portal que me doblaba en porte, y una voz me dijo: "Volverás al útero" ${ }^{51}$.

Entonces crucé el portal. Al principio el temor me invadía, pero vi que lo de adentro era bueno y seguí mi paso por entre el desierto, hasta que llegué a una pequeña ciudad. En ella había tiendas y bazares, templos y lujuria, bares que se multiplicaban como espejismos, gigantescos malls y supermercados, tiendas con anuncios de neón, salones de juego y casas de masaje.

Un hombre se me acercó y me dijo: "Sé quién eres y por qué estás aquí. Acepta mi ayuda". Pero yo desconfié de él y huí de su presencia. Corrí despavorido hasta albergarme en un templo. Me 
senté en solitario a resignarme en el interior de la sabiduría. Entonces vi que un hombre luchaba con una serpiente. Era un Laooconte. $Y$ vi que el hombre era mayor y llevaba bigote y se retorcía con la fiera. Y la fiera no daba tregua. Pensé en ayudarlo y me dirigí hacia él, cuando apareció otro hombre de aspecto desgarbado. Me hizo una señal de calma y luego se acercó al Laooconte. Disectó la serpiente con sus manos y la puso en suelo. El viejo de bigote lo miraba con los ojos encendidos. EI hombre dijo que venía de Argel y que era un amigo. Entonces el viejo preguntó: "¿Qué has hecho?". El de Argel le dijo: "Observa, estos son tus monstruos. Los he puesto aquí para que los veas. Obsérvalos, sólo son lenguaje". Y el viejo miró hacia el suelo donde estaba la serpiente disectada y reordenada, y cuando puso sus ojos sobre ella, ésta desapareció, como una sombra devastada por la luz. Luego los dos hombres salieron del templo, mientras yo seguía perplejo ante lo visto ${ }^{52}$.

Cavilaba en ello cuando otro hombre me habló: "Eran sólo espejismos -me dijo-. El Laooconte que habéis visto no podía desenredarse de su pasado. Había querido ser sacerdote y por eso hablaba de la casa del ser y de rebaños. Conservaba los monstruos de la tradición". Yo le pregunté por el otro hombre que decía venir de Argel, y él me dijo que le conocía, y que era diestro en artilugios de esa naturaleza. Luego me invitó a un pasear por un jardín.

Yo no sabía su nombre. Me dijo que se llamaba Antonio. Luego me habló de la soledad: "Nunca se está solo. Formamos parte de un mismo universo y cada cosa que pasa, cada palabra que se dice, tiene repercusiones grandiosas en lo existente". Y luego me dijo: "No hay diferencia entre la conciencia y la exterioridad. Cuando somos en el mundo, nuestro interior convive con el entorno, como éste con nosotros. Formamos un cuerpo indisoluble. Mis palabras, por ejemplo, son también tuyas". Y luego asintió: "Lo que conozco de ti es el lenguaje que me habla de ti". Entonces le dije: "Pero en el mundo hay lucha y conflicto. No hay unidad entre las partes". Y el hombre me respondió: "Hay lucha, pero está dentro del lenguaje. Es la moneda común que nos unifica, independiente de nuestra condición".

Llegamos a un jardín de vastas proporciones. En el centro había un laberinto y, por los costados, numerosas piletas y juegos de agua. Antonio me dijo: "Elige un lugar". Y yo elegí una pileta que tenía una escultura de dos metros de alto. Le pregunté qué significaba la escultura y él me dijo: "Representa el conocimiento". Entonces le elogié, pues ya le consideraba sabio, y le pedí que me explicara el significado de la obra, pero su respuesta se perdió en algún extraño anaquel de mi memoria.

\section{Coitus interruptus}

Ricoeur se levantó temprano y fue al patio de su casa, en el pequeño invernadero que usaba para leer y escribir ${ }^{53}$. A pesar de las copas y el breve intento de la Roudinesco, que finalmente fue una promesa incumplida, se sentía con vigor para comenzar un libro más. Era increíble el poder (el enigma y la maravilla) de la sexualidad, más después de una vida poco sacudida desde largo tiempo atrás. Ricoeur escribió rápidamente unas notas:

"En el principio era el Verbo... Así comienza un evangelio, así comienza el día para un monje, así comienza un mito y también es así como comienza la vida cada vez que alguien, que se ha detenido a meditarla, tarde o temprano tiene que salir a comprar pan o ir a una fiesta, por ejemplo de una prima misteriosa. En griego se dice "la palabra" y por eso algunos han asumido que por eso todo es lenguaje. En hebreo "decir es hacer" ${ }^{54}$ y por eso algunos piensan que la acción es algo más que lenguaje. La verdad es que no importa, porque la acción es una palabra que unifica la multiplicidad de 
la vida social. Lo más cierto es que se necesitan relatos, mejor si son míticos, para hallarle una hilación a las cosas. Lo dijo un mexicano, cada vez que alguien pregunta por qué, en realidad está pidiendo que le cuenten una historia, porque la definición de un concepto es su historia, su memoria...

"Las definiciones, esas micro coordenadas que pueden coger los objetos de la realidad y aprehenderlos en un recipiente llamado ciencia o disciplina o teoría o descripción rigurosa, no son más que justificaciones a una frustración, como la que refleja bien Woody Allen ${ }^{55}$ cuando cuenta que le preguntó a un viejo rabino, muy sabio, cual era el sentido de la vida. Se lo dijo, pero en hebreo y él era muy joven y vivía en Nueva York. Así que nunca más supo la respuesta y el rabino murió al poco tiempo. Queda también, por supuesto, la sutil ironía o la esquiva risa que es lo que queda después de la acción."

Entonces se detuvo. Se dio cuenta que no quería escribir ningún libro más. Es más, ni siquiera tenía un esquema temático. Se puso de pie y caminó hacia el jardín afuera del invernadero.

Ya no volvió jamás.

\section{El delirio de Mak}

Mak empezó a entrar de lleno en su particular delirio. Se salió de la línea pues. Se alejó a tal distancia que podía verse a sí mismo allá en el sillón junto a Tomás y junto al viejo. Y seguía alejándose más y más hasta que dejó de preocuparse por lo que dejaba atrás y alzó la vista hacia donde fuera que aquel aroma de pipa lo llevaba.

Pronto la casa ya ni se disipaba entre el manto de nubes y estrellas que se abría delante de sí. Como presa de una velocidad vertiginosa la línea del horizonte parecía inmóvil y Mak devenía un punto que se precipitaba hacía ella.

Pero en realidad, lo que adquiría velocidad no era Mak si no el horizonte. Era éste el que se abalanzaba sobre Mak operando un pliegue descomunal del espacio. Hasta que el horizonte engulló a Mak y a toda la mansión. Ahora el tiempo se fragmentaba, uno podía notar una extrema ensoñación mientras apenas se lograba entrever algo difuso, borroso. Mak se resistía a seguir el movimiento del horizonte. Notaba como sus piernas eran arrastradas, ancladas como estaban en el reflujo energético de la fusión de horizontes. Pero Mak quería seguir, quería volver. Pero lo único que logró ver antes de formar parte del tiempo fragmentado. Antes de desvanecerse en una ensoñación eterna, lo que vio fue aquella sonrisa malévola de unos dedos que bailan sobre un teclado. Compitiendo entre ellos para ver cuál será el que pondrá fin a esta historia.

\section{F I N}

\section{Epílogo uno ${ }^{56}$}

—QQué hay detrás de la ventana? -les pregunté.

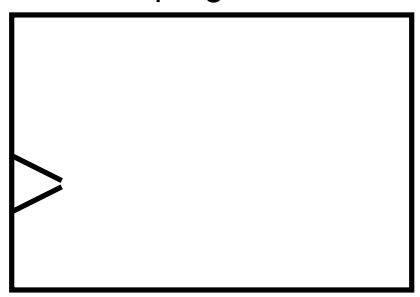


_Una estrella — dijo Mondaca.

—Un pico — dijo Lorena, y todos nos echamos a reír.

— La punta de una plancha mirada desde arriba — dijo Conce. Enseguida me consultó intrigada-: ¿Qué hay?

Es Lisa Simpson —dije.

—¿Quién es Lisa Simpson? —replicó Lorena.

_Una de las hijas de los Simpson —respondí.

Eso es muy rebuscado — dijo Mondaca.

Luego dibujé otro rectángulo y les volví a preguntar.

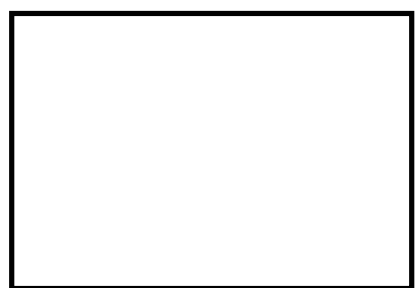

_No hay nada —afirmó Lorena.

—No, sí hay algo — replicó Conce—. Una sábana blanca secándose al sol.

-Apuesto que hay nieve. Un volcán nevado — dijo Mondaca.

— Hay una hoja en blanco — concluyó Lorena.

— ¿Cómo va a ser una hoja en blanco? — sentenció Mondaca — . Tendría que ser más grande que la ventana.

— ¿Por qué no puede ser así? — dijo Conce—. Puede ser una ventana chiquita.

Mientras discutían sobre eso, les hice un tercer rectángulo.

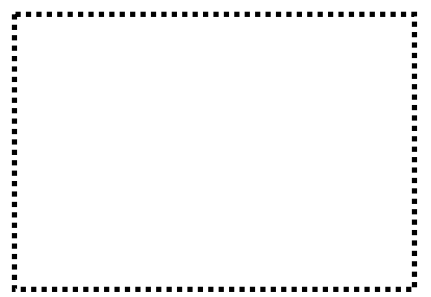

— ¿Qué hay detrás de la ventana? 


\section{Epílogo dos}

Tomás despertó con la peor resaca de su vida. Salió de la cama para echarse de nuevo en un sofá, pasando antes a la cocina por un vaso con agua y un par de aspirinas. Reclinó la cabeza, abrió los ojos lo más que pudo dirigiéndose al techo y dijo:

—A mí nadie me engaña. Ayer se cometió un asesinato.

Dicho esto cerró de nuevo los ojos, sacudió bruscamente la cabeza e hizo un gesto de extrañeza. Lo había dicho absolutamente sin pensar. Se puso de pie experimentando un leve mareo y se dirigió de prisa a su habitación buscando indicios de lo ocurrido la noche anterior. Ahí estaba su cámara fotográfica. "Fotos, claro, seguramente tomé muchas fotos anoche y estas me aclararán la situación", habría pensado. Sacó el rollo de la cámara y lo puso sobre el escritorio. Ahí se percató de que había garabateado unas notas durante la madrugada. Era un texto que parecía haber salido de la Biblia más que de la mente sencilla de un intento de periodista como él. Pero por la letra, sin duda lo había escrito él.

Quiso poner un poco de orden en la habitación antes de ir al laboratorio fotográfico. Así descubrió que bajo su cama yacía un hombre. Con la sorpresa se le quitó el dolor de cabeza.

— ¡Hey, tú, despierta! ¿Qué haces debajo de mi cama? -increpó Tomás al extraño gritándole al oído.

—Tomás, tranquilo. Soy Mak, ¿recuerdas? —contestó aquél apenas abriendo los ojos.

—Mak, sí... Mak.

— ¿Te sucede algo? ¿Te sientes bien?

-Sí... no... no sé... Es que esa fiesta fue una locura. Ocurrió un asesinato, sí, la amiga de Concepción que hizo la fiesta mató a Hans, el amigo del profesor Ludwig, y luego nosotros fumábamos, y yo escribí unas cosas muy raras que seguramente aluciné.

-Tomás, pero si fue Concepción quien hizo la fiesta. Pero para rarezas figúrate que yo soñé o aluciné que unos maliciosos científicos de un laboratorio de psicología social se divertían escribiendo nuestras vidas, y lo peor fue que competían por poner fin a nuestra historia.

-Espera, espera, detente. ¿Cómo que fue Concepción quien hizo la fiesta?

—Sí, claro. Yo la conocí en Estados Unidos, ella acompañaba a Richard Rorty...

- Me cuentas de camino al laboratorio fotográfico. Todo es demasiado confuso para mí en este momento de "normalidad" y espero que estas fotografías me ayuden a aclararme -interrumpió Tomás, que se comportaba de forma impulsiva.

Salieron a la calle y se dirigieron al coche de Tomás.

— ¿Puedes ir guardando estas cosas en el maletero? Olvidé mis gafas, ahora vuelvo - pidió Tomás a Mak.

Mak abrió el maletero y se quedó estático ante lo que vio allí dentro, hasta que Tomás volvió. Temblando musitó:

-Tomás, esto es un cadáver. 


\section{Epílogo tres}

Sumergida en su horizonte, la mansión vio las primeras luces del amanecer bajo el signo inexorable del abandono. Sus lánguidas paredes maltratadas por la impronta del tiempo anunciaban un graffiti extrañísimo, un jeroglífico hirsuto queriendo revelar algún secreto. Su portón derruido tenía manchas oscuras, herederas silenciosas de historias nunca vistas. En el tejado se abrían un par de socavones sucios que parecían no tener fondo. Un letrero de lámina oxidada, moviéndose intermitente con el viento, permitía leer: "se vende". Sus jardines eran ya un océano de zarzas y tristeza. Una cerca rota rodeaba el lugar, un perro hambriento olfateaba el montículo de basura y a lo lejos, pasaba volando un ave de rapiña. Desde dentro aun se oían voces distantes perdiéndose en su retorno infinito, en su búsqueda frenética. Nunca habría respuesta. indetenible.

A unos cuantos metros de aquel recinto, la ciudad gigante empezaba ya su marcha

\section{Epílogo cuatro: epifanía.}

De pronto, todos escucharon.

No era la voz de Gadamer, quizá si, desde el más allá. O tal vez desde un más acá insólito. Pero era una voz, quizá una imagen o una epifanía. El caso es que lo escucharon: Max. Alfred, Niklas, Anthony, Paul, Mak, Concepción, Daniel, Alfonso, Tomás, todas y todos. Era como una música de olvido. Con un sabor de esos que sólo ocurren cuando se está yendo la infancia y no sabes qué viene para tu cuerpo ni tu alma. El sonido del silencio:

Ella estuvo todo el tiempo allí, delante, inexorable. Cada circunstancia, cada vuelco de las situaciones, en las intenciones y en las inintenciones, a veces acechaba como una fiera dispuesta a atraparte, a devorarte, sin importar si quedabas anulada o morías en el acto, si agonizabas o si desaparecías en el éxtasis.

Donde ya no estaba era en el pasado, cada momento que te detenías a pensar, a recordar, a tratar de mirar lo que había sucedido, entonces ella no estaba más. Nadie sabe como sucedía, como podía existir en el tiempo, porque el futuro no existe en tanto no ha acontecido y es el presente lo que importa en tanto si acontece, en tanto dura. Pero ocurre que ella no estaba presente. No. No puede decirse que estaba presente, porque su presencia era, cómo decirlo, una no presencia, una sombra de cada acción, de todo movimiento. Es como si ella inventara otra dimensión del tiempo presente, una dimensión donde el presente no es, donde el pasado emerge ineludible y donde todo está por venir. Ella es pues, promesa y acto, es sentido.

Ya está dicho. Ahora se ha esfumado. Cada vez que invocamos un nombre, un conjuro mágico para aprehenderla, entonces ocurre siempre lo mismo, desaparece. Por eso los dioses ${ }^{57}$ participan en este juego maravilloso de la búsqueda de ella. Por eso luchan y por eso se fascinan al punto de hacerse humanos, frágiles, equívocos. Porque también los dioses intuyen que toda esperanza reside en ella.

Ella, mi prima. 


\section{Bonus track}

A propósito de "La Guerra de las Galaxias":

"Donde dice FUERZA, reemplace por LENGUAJE"

(Maestro Yoda)

"Llegué tarde pero sin sueño"

(Relativismo)

"En el principio fue el sexo"

(Adán)

"Sexo: luego existo (después pienso)"

(Freud a propósito de su cuñada)

\section{"Dios ha muerto"}

(Nietzsche)

\section{"Nietzsche ha muerto"}

$$
\text { (Dios) }
$$

"Posdata: Difundan la noticia"

"Como todo joven yo quise ser un genio, pero afortunadamente intervino la RISA"

(Maestro Eckhart)

"Verdad y Método III: La última palabra"

(Libro aprócrifo de Gadamer) 
"No me gusta interpretar películas porno: siempre me salgo antes de la mente del autor" (Schleiermacher)

\title{
"Nada es nuevo bajo el sol"
}

(Dilthey)

"Lo que sea que suene"

(John Shotter)

"Yo quería acción, pero ella me dio texto"

(Paul Ricouer)

"iii¿Alguien me puede servir una copa?!!!"

(Stephen Hawking)

Y luego, con la copa en la bandeja...

iiiiPero con pajita, hijos de puta!!!!

\author{
"¡Toma Mami!" \\ (Taxista cubano)
}

"Sí a la Constitución Europea, pero con doble estructura"

(Giddens)

"La acción me pone cachonda"

(Santa Teresa)

"Mal pistolero el que se queda con la última bala"

(John Wayne, en relación a "Verdad y método III") 


\title{
"Esto no es un ensayo"
}

(Magritte a propósito de este trabajo)

\section{"Imagínense que han aprobado el curso"}

$$
\text { (Lupi) }
$$

"De cada diez personas que ven televisión, cinco son la mitad"

(Gianni Vattimo)

\section{"Si no llegó es porque no vino" \\ (El filósofo de Güemes)}

"Todo lo que sube baja, a menos que se quede arriba"

(Profesor Ludwig)

"...Y se abrió un claro en el bosque"

(Martín Heidegger)

"... Y en el bosque pasó de todo"

(La Caperucita)

"Un ejemplo de acción no racional: me voy a mear"

(Max Weber)

\author{
"¿EHH? ¿AHH? ¿UHH?" 58
}

(Jürgen Habermas) 
"Ayer pasé por tu casa y me tiraste un limón. Como no me gustó el arroz con leche, metí el dedo en la cerradura"

(Deleuze y Guattari)

\author{
"Oye chato, ¿te vienes a cenar?" \\ (El gato de Lupi)
}

"Masticar chicles con azúcar es de puta madre"

(El uno de cada diez dentistas que no recomienda chicles sin azúcar)

"Tócatelos"

(Sam)

"Boys, boys, boys"

(Umberto Eco)

"Imagina un mundo sin fronteras/ sin límites/ que todo sea amoooor./ Imagina" (John "Anti-Eco" Lennon)

"Luces, cámara, jacción!"

(Mónica Lewinsky)

"¿Quién puso SúperGlue en la loza del aeropuerto?"

(El Papa)

"Bueno, bueno... ya déjenme tranquila"

(Acción social) 
"Cada vez que nos reunimos se abre un horizonte desfondante"

(Autores de este texto)

"Cada vez que hacemos un trabajo se abre una dimensión del universo, se inaugura un portal de luz, y encima en alemán"

(Autores de este texto)

"No seáis hiperlactantes (mamones)"

(El universo)

"Dios: dame paciencia... ipero ya!"

(Invitado a reunión de elaboración del texto)

\section{"Brrbbbgrgrgrggrgrg"}

(Yann Bona al final del trabajo, contestando una pregunta de Raúl)

"Como dijo Camilo: ¡Hagan lo que les dé la gana con el texto"

(Raúl García)

"¿Qué- qué Fidel? ¡Que se acabó la fiesta! ¿J Q Qué- qué Fidel J\&? ¡Que se acabó la fiesta!

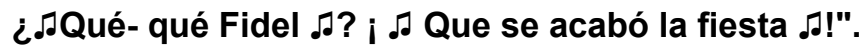

(Fidel tratando de poner orden en la Asamblea)

"Y cuando despertó, la fiesta seguía ahí"

(Augusto Monterroso) 


\section{Notas}

${ }^{1}$ Dado que la acción es un concepto tan multívoco, entendido con muy diversos sentidos en las teorías sociales, algo queda siempre confuso. Entonces decidimos hacer una virtualización del concepto de acción social: es decir lo problematizamos, lo sacamos del centro o punto de arranque, que suele ser la función de una definición. Para ello tomamos la idea de espacio vacío del estructuralismo, que es el motivo o fin en la trama, lo que todos los actores, agentes o actantes (como los llama Greimas) buscan y en el devenir o proceso se van transformando hasta llegar al final del relato. Claro, lo que todos buscan moviliza a los agentes y se presenta como horizonte, siempre inalcanzable. Cuando parece ser tocado, entonces ocurre la fusión de horizontes, quizá ocurre la comprensión.

Nuestro juego consiste en ir creando actores y poniéndolos en el juego de una trama, en conversaciones y acciones, llevando al relato las ideas o teorías que sabemos o nos interesan, haciendo un juego según la regla de que la trama nos irá enredando y hemos de ser fieles a los caracteres y las palabras que vayamos creando en la escritura colectiva. No sabemos que ocurrirá, pero lo que importa es que juguemos y ojalá sea divertido. Adelante pues.

${ }^{2}$ Por koiné se entiende "lenguaje común". Vattimo (1995) explica cómo la hermenéutica debe pasar a ser otra cosa que una koiné. Otra cosa que una genérica filosofía de la cultura. La hermenéutica debería reconocer su "vocación nihilista", en el sentido de Nietszche, para así afirmarse como algo realmente radical en tanto acaece una sustitución de los hechos por las interpretaciones. Coninuando la labor de crítica a la metafísica ya iniciada en Heidegger.

${ }^{3}$ Vega, M (2001).Tiempo y narración en el marco del pensamiento posmetafisico. Espéculo. Revista de estudios literarios. Universidad Complutense de Madrid.

http://www.ucm.es/info/especulo/numero18/ricoeur.html

\footnotetext{
${ }^{4}$ Véase www.markryden.com

${ }^{5}$ Puede revisarse: Durkheim, E.(1974). Las reglas del método sociológico. Madrid: Morata.

${ }^{6}$ Para valorar con mayor amplitud el tema, es posible revisar: Schütz, A.(1972). Fenomenología del mundo social. Buenos Aires: Paidós.

${ }^{7}$ Weber, M. (1968). Economy and Society. Totowa, N.J.: Bedminster Press.

${ }^{8}$ La evocación de Madonna viene al caso porque hacia fines de los años 80, apareció en la ciudad de Morelia, México, una publicación barata perteneciente a la llamada "prensa del corazón" (e imposible de recuperar en este momento), en cuya portada podía verse una foto de la diva semidesnuda, junto a un titular que decía: Madonna, una chica en acción. (N. del E.)

${ }^{9}$ Véase: Parsons, T. (1988). El sistema social. Madrid: Alianza.

${ }^{10}$ Giddens, A. (1993). Las nuevas reglas del método sociológico. Buenos Aires: Amorrourtu.

${ }^{11}$ Quien se interese en la reflexión de Niklas Luhmann puede revisar: Autopoiesis, acción y entendimiento comunicativo. En: Zeitschrift für Sociologie. Año 11, № 4, pp. 366-379. Y también: La improbabilidad de la comunicación. En: Revista Internacional de Ciencias Sociales 33, № 1 pp. 136-147.

${ }^{12}$ Paul de Man (1985) ha insistido que esta cita de Yeats puede interpretarse como una invitación a la actividad deconstructiva.
} 
${ }^{13}$ En lo teórico, Enrique Lihn no tiene nada que ver con Derrida y la hermenéutica. Sí tiene mucho que ver con la antipoesía y el coloquialismo lírico, que curiosamente están muy emparentados con la deconstrucción y el discurso posmoderno. El verso pertenece al poemario Diario de Muerte (1988).

${ }^{14}$ Según Bloom no podría hablarse de canon del suspense, pero sí de autores canónicos que lo abordan. Por ejemplo, Graham Greene y un par de narradores judío- estadounidenses.

${ }^{15}$ Sobre esta respuesta, Putnam (1995) ha sido enfático. Le parece que Mondaca adopta una posición relativista endeble: "(...) es como un espejismo que parece real a cierta distancia: se divisa como si fuese un oasis en el desierto, nos acercamos increíblemente sedientos, y después todo se desvanece dejando nada más que arena".

${ }^{16}$ Padawan es el nombre que reciben los jóvenes aprendices de caballeros jedi en "La guerra de las galaxias".

${ }^{17}$ Para ver la relación entre Rorty y los Estados Unidos que en el texto se sugiere, aconsejamos la lectura del capítulo del libro Municiones para disidentes (2002) de Tomás Ibáñez: "Richard Rorty: Entre la seducción y la sospecha".

${ }^{18}$ En ciertos restaurantes chinos de Cerdanyola del Vallès, provincia de Barcelona, al finalizar la comida, una joven oriental ofrece a los clientes consumir una exótica bebida en cuya botella yace sumergido un lagarto grisáceo. A este trago se le denomina "chivito chino".

${ }^{19}$ Hans-Georg Gadamer escribió "Verdad y método I" y "Verdad y método II". Pero no escribió nunca "Verdad y método III". De allí la sorpresa de los asistentes.

${ }^{20}$ Lo que sigue es una versión ligeramente retocada del intento de motín producido en un pub londinense por parte de "The Angry Brigade" y que queda documentada en un libro titulado "La revolución del deseo" del que desafortunadamente no logramos encontrar la referencia. El hecho que al final Umberto Eco se decida a quemar la fiesta guarda relación con los hechos relatados por "The Angry Brigade" y a su vez con el incendio de la biblioteca de su novela "En el nombre de la rosa".

${ }^{21}$ El problema de qué o de quién depende la interpretación del texto es parte fundamental del problema hermenéutico. La posición de Gadamer en "Verdad y Método" es que no depende de quién lo elaboró (qué quiso decir) ni de quien la lee, sino de la tradición. El viejo Hans tampoco estaría entonces de acuerdo con Concepción.

22 "Telebasura" es el término con el que los "bienpensantes" intelectuales de España, avalados ahora por el Estado, han designado a todos aquellos programas de televisión que según su criterio atentan contra la cultura de los españoles, y afectan a los ojos inocentes de los niños. Se refieren específicamente a reality shows, talkshows, prensa rosa y chismes de espectáculos. "Programas infames de televisión", diría el profesor Lupicinio Íñiguez con mucho sarcasmo.

${ }^{23}$ El profesor Ludwig fundó el periódico "Decir es hacer" allá por el año 2000, influenciado por las ideas de un artículo de Tomás Ibáñez (2000) en torno a la acción social, en el que recuerda entre otras cosas "Ios comentarios de Wittgenstein acerca de la imposibilidad de identificar las intenciones con independencia de las acciones" (p. 48)

24 "El sujeto no pertenece al mundo, sino que es un límite del mundo", dice el aforismo 5.362 del Tractatus logicophilosophicus de Wittgenstein (1918).

${ }^{25}$ Versos de la canción "Preguntas desde un ocho de marzo" del cubano Vicente Feliú.

${ }^{26}$ Gadamer hace una interesantísima reflexión en relación al arte, entendido como juego como símbolo y como fiesta. Véase: Gadamer, H.G. (1991). La actualidad de lo bello. Barcelona: Paidós-ICE/UAB. 1996. Muy importante también resulta la Introducción al referido texto, titulada El arte después de la muerte del arte, escrita por Rafael Argullol. 
${ }^{27}$ Aquí tequila sunrise es por una parte un guiño a los mexicanos con quienes hemos escrito este texto y que como bien anuncian "Dios ha muerto", pero en México siguió vivo muy a pesar de Nietszche. Y por otro lado es también un fragmento de una canción de Cipress Hill. Como muchos de estos autores yacen precisamente en estos momentos en una "colina de cipreses" nos pareció pertinente añadir el coctel de dicho nombre.

${ }^{28}$ Recomendamos la lectura del texto de Dutt, C. (Ed). (1998). En conversación con Hans-Georg Gadamer. Hermenéutica. Estética. Filosofía práctica. Madrid: Tecnos.

${ }^{29}$ Canción mexicana popularizada en la voz del icónico Pedro Infante.

${ }^{30}$ Elisabeth Roudinesco, autora de la biografía de Lacan: Lacan. Esbozo de una vida, historia de un sistema de pensamiento, FCE.

${ }^{31}$ Es evidente, si se ha leído la biografía de Lacan escrita por la Roudinesco, que lo que sigue se inspira en esa "historia novelada" que sugiere más de lo que dice. Hay cosas que son ciertas, pero con Lacan nunca se sabe la diferencia entre lo ilusorio y lo que puede acercarse a una verdad con (algún) significado.

${ }^{32}$ Para una revisión del colonialismo en la constitución de la modernidad en Europa, cf. Enrique Dussel (1993), El encubrimiento del otro. Hacia el origen del mito de la modernidad, Quito: Ediciones ABYA - YALA, 1994.

${ }^{33}$ El nombre de la rosa, Madrid: Lumen, 1982.

${ }^{34}$ Ver nota 2.

35 Con esta contundente frase finaliza Wittgenstein su Tractatus, refiriendo a que no se puede analizar lógicamente aquello que pertenece a lo inefable, no se puede poner lógica a aquello que no lo tiene.

${ }^{36}$ Para lbáñez (2001) esta discusión es paradigmática entre las posturas esencialistas y antiesencialistas.

37 Comezón conocida como Cartesianitis aguda. Se produce, al parecer, por el olor que expelen ciertos argumentos esencialistas y dogmáticos. Genera una especie de "Mmmmhhhh" en la nariz, y una cierta reticencia en la piel.

${ }^{38}$ Gadamer comentó para "Decir es hacer": "El caso es que no es el hombre el que dispone de las cosas, sino que son las cosas las que disponen de él. Es como si el hombre fuera raptado por la verdad o por las sombras que él mismo contribuye a evocar".

${ }^{39}$ No se ha podido dilucidar el nombre y el origen de la yerba. Mamani (2002) ha señalado que se trata de una yerba sudamericana conocida como quichá, que crece en la frontera de Perú y Ecuador. Para Moreno (2003), se trata de una variante sureña del peyote, que los indios yaquis consumen para realizar prácticas de transegridad. Según Olivera (2004) no es ni quichá ni peyote, sino que es ayahuasca, una yerba usada por una tribu de amazonas de pelo azabache.

${ }^{40}$ Paz, obsesionado con Fernando Pessoa, llegó a creer que él mismo era un heterónimo del poeta portugués. En algunos momentos no se sabe quién es el que habla: si Fernando Pessoa imitando a Octavio Paz a través de Alberto Caeiro, u Octavio Paz traduciendo a Pessoa, en una calurosa mansión de Nueva Delhi, India. El siguiente fragmento agudiza la discusión: "El misterio de las cosas, ¿dónde está?/ Si apareciese, al menos, / Para mostrarnos que es misterio. / ¿Qué sabe de esto el río, qué sabe el árbol?/ Y yo, que no soy más, ¿qué sé yo?/ Siempre que veo las cosas/ Y pienso en lo que los hombres piensan de ellas/ Río con el fresco sonido del río sobre la piedra".

${ }^{41}$ La obra fue estrenada en Heildelberg, en 1966.

${ }^{42}$ Vattimo (1991) cree que se trata de una obra de carácter gadameriano.

43 Ibáñez (2001) comenta esta escena en su artículo "La acción social dice adiós a Descartes".

44 Para Ricoeur los textos proyectan mundos posibles, modos posibles de ser: "únicamente la escritura, al liberarse no sólo de su autor, sino también de la estrechez de la situación dialogal, revela su destino de discurso, que es el de proyectar un mundo". 
${ }^{45}$ Aquí retomamos el concepto de Shotter (referencia) dualidad estructural, que sencillamente quiere decir una estructura en proceso de estructuración. Es decir, algo en lo que su propia condición de realidad lo realiza o determina paso a paso. Como el caso de la acción, que es en la medida que se hace, y como se haga va a determinar lo que es.

${ }^{46}$ Es el cóctel que pide el Gran Lebowski en la película del mismo título de los hermanos Cohen. Lleva kalhúa, vodka y crema de leche.

${ }^{47}$ La frase "Yo creo que es mejor expresar los sentimientos cuando surgen. A veces uno se queda con ellos demasiado tiempo" aparece efectivamente en la película "Tigre y Dragón".

${ }^{48}$ La misma idea pero con otras palabras aparece en el libro de Lao-tse; "Tao te ching".

${ }^{49}$ Se ha dicho que esta etapa del delirio tiene que ver con el concepto de fusión de horizontes de Gadamer. Vattimo (1998) no está del todo convencido.

${ }^{50}$ Vattimo (1991) reconoce reminiscencias claramente nietzscheanas en esta aseveración.

${ }^{51}$ Sobre este fragmento del delirio, Peter Sloterdijk comentó para Der Spiegel: "Tal vez nunca salimos del útero" (21/04/05). Ver, además, Sloterdijk (2004).

${ }^{52}$ Es evidente el símil: Laooconte/ Heidegger y Disectador/ Derrida. Antonio Penedo, en su libro Matrix: de la leyenda Artúrica al discurso Ciberpunk, comenta que él tuvo un sueño semejante.

${ }^{53}$ Cf. Charles E. Reagan, Ricouer. His life and his work, Chicago University Press, 1998.

${ }^{54}$ La palabra dabar , en la Biblia hebrea, significa "decir" y también "hacer".

${ }^{55}$ Cf. Cómo acabar de una vez por todas con la cultura, Madrid: Tusquets, [1974].

${ }^{56}$ Este final fue profetizado por Bolaño (1998). Al respecto, Richard Rorty comentó: "Me parece que puede entenderse como una metáfora del problema de la filosofía especular (...) Lo que tantas veces he dicho: esa filosofía que se basa en la idea de un yo frente a la realidad natural, más o menos describible, es un sin sentido. Este final tiene ese toque de ironía que me gusta, que le da ese sabor pluralista y abierto, tan necesario en estos tiempos" (Revista Times, marzo de 2005). Sobre estos comentarios, Jürgen Habermas señaló: "Creo que Richard ha errado en su afirmación. Éste final es una clara muestra de mi tesis sobre la acción comunicativa" (Le Monde Diplomatique, abril de 2005).

57 Para una comprensión de lo religioso desde la fenomenología cf. José Severino Croatto, Experiencia de lo sagrado. Estudio de fenomenología de la religión, Navarra: Verbo Divino, 2002.

${ }^{58}$ Para mayor precisión en los criterios de Habermas, puede revisarse: Habermas, J. (1989). Teoría de la acción comunicativa 1: Racionalización de la acción y racionalización social. Buenos Aires: Taurus.

\section{Referencias}

Allen, W. (1974). Como acabar de una vez por todas con la cultura. Madrid: Tusquets.

Austin, J. L. (1962). How to do things with words. Cambridge: Harvard University Press.

Bergson, H. (1977). Memoria y Vida: textos escogidos por Gilles Deleuze. Madrid: Alianza editorial, 2004.

Bolaño, R. (1998). Los detectives salvajes. Anagrama: Barcelona.

Croatto, José Severino (2002). Experiencia de lo sagrado. Estudio de fenomenología de la religión. Navarra: Verbo Divino. 
D’Agostini, F. (1997). Analíticos y continentales. Guía de la filosofía de los últimos treinta años. Cátedra: España, 2000.

Domingo Motaralla, A. (1991). El arte de poder no tener la razón: la hermenéutica dialógica de H.G. Gadamer. Publicaciones Universidad Pontificia de Salamanca: Salamanca.

Deleuze, G. \& Guattari, F. (1994). Mille Plateaux. París: Ed. de Minuit, 1980.

Durkheim, E. (1974). Las reglas del método sociológico. Madrid: Morata.

Dussel, E. (1993), El encubrimiento del otro. Hacia el origen del mito de la modernidad, Quito: ABYAYALA, 1994.

Dutt, C. (Ed). (1998). En conversación con Hans-Georg Gadamer. Hermenéutica. Estética. Filosofía práctica. Madrid: Tecnos.

Eco, U. (1980), El nombre de la rosa, Madrid: Lumen, 1982.

Gadamer, H.-G. (1975), Verdad y método. Salamanca: Sígueme, 2003.

Gadamer, H.-G. (1986), Verdad y método II. Salamanca: Sígueme, 2002.

Gadamer, H.-G. (1991). La actualidad de lo bello. Barcelona: Paidós/ ICE-UAB,1996.

Giddens, A. (1993). Las nuevas reglas del método sociológico. Buenos Aires: Amorrourtu.

Habermas, J. (1989). Teoría de la acción comunicativa 1: Racionalización de la acción y racionalización social. Buenos Aires. Taurus.

Hernández- Pacheco, J. (1996). Corrientes actuales de la filosofía. Tecnos: Madrid.

Ibáñez, T (2001). Municiones para disidentes. Barcelona: Gedisa.

Ibáñez Gracia, T. Algunas reflexiones en torno a la acción social, en Inguruak.28.2000.

Lihn, E. (1988): Diario de Muerte. Universitaria: Chile.

Luhmann, N. (1982). Autopoiesis, acción y entendimiento comunicativo. Zeitschrift für sociologie 11 (4), 366-379.

Luhmann, N. (1981). La improbabilidad de la comunicación. Revista Internacional de Ciencias Sociales 33 (1), 136-147.

Parsons, T. (1988). El sistema social. Madrid: Alianza.

Paz, O. (1999). Obras Completas. Galaxia Gutemberg: Barcelona.

Reagan, E. Charles (1998). Ricoeur. His life and his work. Chicago University Press.

Ricoeur, P. (2001). Del Texto a la Acción: Ensayos de hermenéutica II. México: Fondo de cultura económica. 
Roudinesco, E. (1994). Lacan. Esbozo de una vida, historia de un sistema de pensamiento. Buenos Aires: FCE.

Schütz, A. (1972). Fenomenología del mundo social. Buenos Aires: Paidós.

Searle, J. (1969). Actos de habla. Madrid: Cátedra, 1994.

Sloterdijk, P. (1999). Esferas II. Globos. Madrid: Siruela, 2004.

Vattimo, G. (1995). Más allá de la interpretación. Barcelona: Paidós.

Weber, M. (1968). Economy and Society. Totowa, N.J.: Bedminster Press.

Wittgenstein, L. (1918). Tractatus logico-philosophicus. Madrid: Alianza, 2003.

Zúñiga, J. (1995): El diálogo como juego: la hermenéutica filosófica de Hans Georg Gadamer. Universidad de Granada: España 